NBER WORKING PAPER SERIES

CONSUMPTION GROWTH PARALIELS INCOME GROWTH:

SOME NEW EVIDENCE

Chris Carroll

Lawrence $H$. Summers

Working Paper No. 3090

NATIONAL BUREAU OF ECONOMIC

1050 Massachusetts Avenue

Cambridge, MA 02138

September 1989

The authors gratefully acknowledge funding from the National Science

Foundation. We would also like to thank David Cutler, James Poterba, Greg

Mankiw, Olivier Blanchard, Daniel Feenberg, and the members of the M.I.T.

Public Finance Lunch, Money Lunch, and Money Workshop for constructive

comments. Thanks especially to Knut Morck and Alessandro Missale for generous help in obtaining data, and to Steve Zeldes for help on the uncertainty theory. Remaining errors are of course our own. This paper is part of NBER's research programs in Economic Fluctuations and Financial Markets and Monetary Economics. Any opinions expressed are those of the authors not those of the National Bureau of Economic Research. 
NBER Working Paper \#3090

September 1989

\section{CONSUMPTION GROWTH PARALLELS INCOME GROWTH: SOME NEW EVIDENCE}

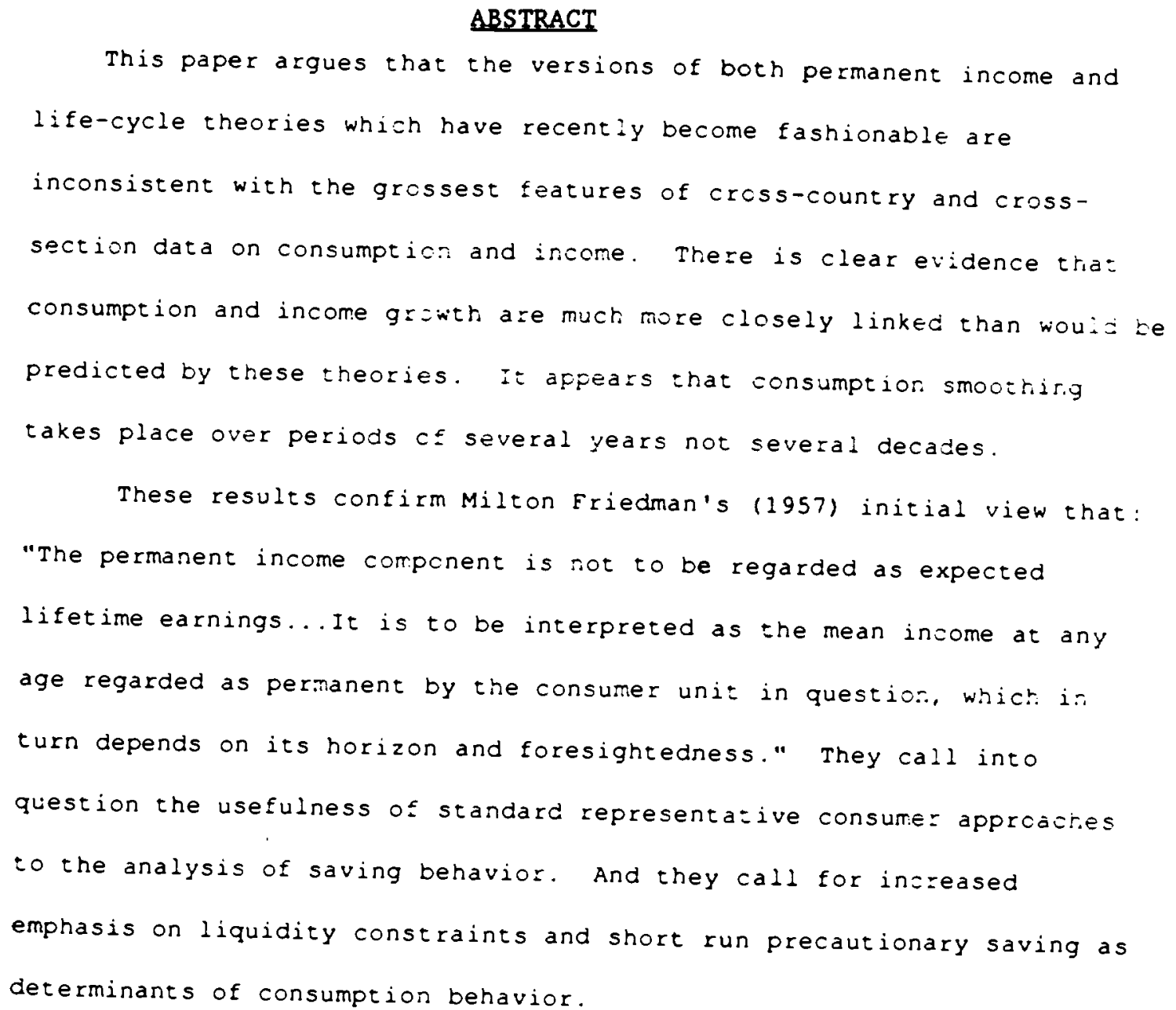

Chris Carrol1

MIT

Department of Economics Cambridge, MA 02139

\author{
Lawrence $H$. Summers \\ NBER \\ Harvard University \\ Department of Economics \\ Littauer Center 229 \\ Cambridge, MA 02138
}




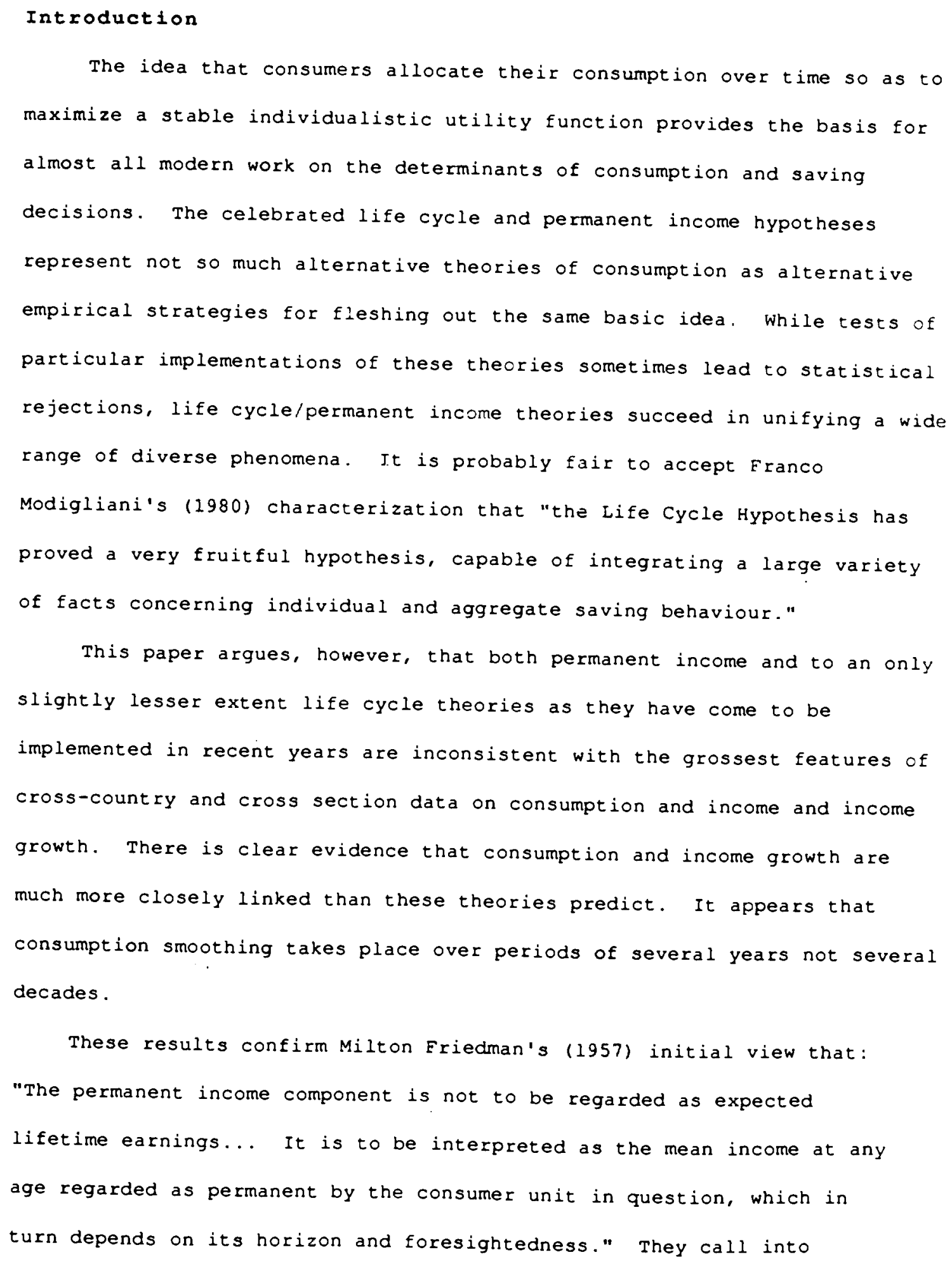


question the usefulness of standard representative consumer approaches to the analysis of saving behavior. And they call for increased emphasis on liquidity constraints and short run precautionary saving as determinants of consumption behavior.

This paper is divided into five sections. Section I presents the rational expectations version of the Permanent Income Hypothesis which has been increasingly popular in empirical macroeconomics recently, and draws out the low frequency implications of this hypothesis. The principal implications on which we concentrate are, first, that labsent capital market imperfections) the anticipated rate of growth of income should be unrelated to the rate of growth of consumption, and second, that the rate of interest should be a powerful determinant of the rate of growth of consumption. We present evidence which challenges both of these propositions. We demonstrate that over periods of several years there is nearly perfect equality between rates of income growth and consumption growth. These facts hold both across countries and, within countries, across different eras when productivity increased at different rates. The prediction of the permanent income hypothesis that consumption growth and anticipated income growth are unrelated is clearly refuted. We next argue that these facts cannot be explained by imperfections in the international capital market, since there is no evidence that countries with more rapid consumption growth have higher rates of return on bonds or other assets. Section II asks whether recognizing that consumers have finite lifetimes helps in understanding these stylized facts. This is plausible a priori. Because the gap in lifetime income between old and new generations ones is greater in rapidly than in slowly growing countries the 


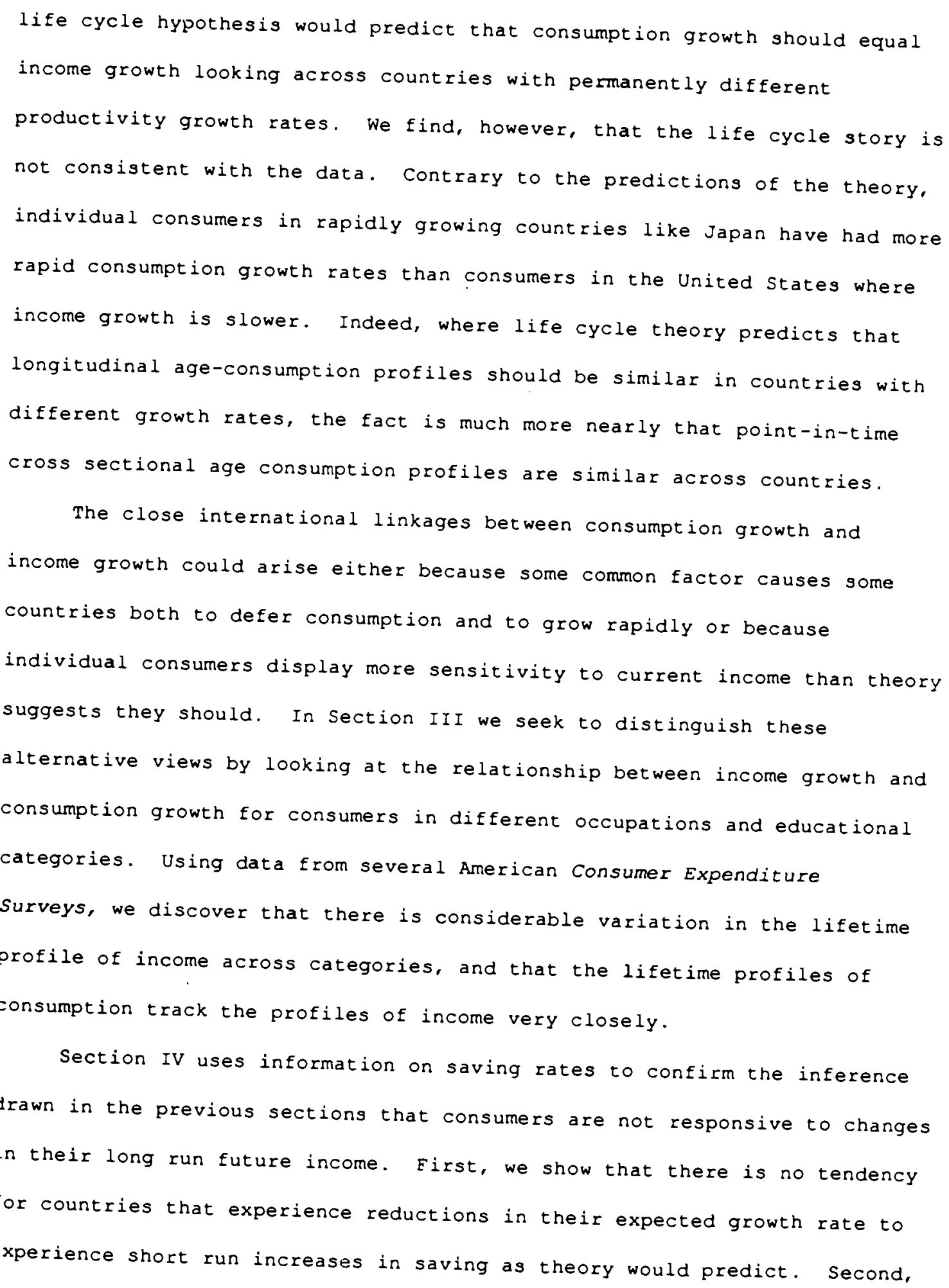


we test the pure life cycle theory's prediction that when a country experiences a sharp productivity slowdown as the United States has in recent years, there should be a tendency for the relative saving rate of the young to increase greatly. This prediction is not borne out. Third, we document that contrary to the theory's prediction there is no tendency for young people in occupations where income rises rapidly to have lower saving rates than those in occupations where income rises slowly. Section $V$ discusses the implications of these results for consumption theory. We suggest that both our data and the available time series evidence is consistent with Milton Friedman's view that people save to smooth consumption over several years in the face of uncertain income but because of liquidity constraints, caution or shortsightedness do not seek to smooth consumption over longer horizons. We follow the recent work of Deaton (1989) in arguing for a "buffer stock" view of saving as appropriate for most consumers. This view is supported by tabulations from a longitudinal data set on tax returns suggesting that about $40 \%$ of the population never earned more than $\$ 100$ in dividend and interest income over a six year period, $30 \%$ of the population earned more than $\$ 100$ in every year, and $30 \%$ earned more than $\$ 100$ in some but not all years. The buffer stock view of saving is attractive in another respect. If the size of the stock is proportional to income, then one would expect to observe the close relation that is actually observed between saving rates and income growth. We also present evidence, however, that suggests that even if the typical consumer may be accurately described by the buffer stock model, the typical saver may not be. This discrepancy is possible if the distribution of saving is more unequal than the distribution of consumption, so that the great majority of dollars saved are not saved by the typical consumer but 
rather by a small number of very wealthy consumers who have very high saving rates. We argue that the apparent importance of the distinction between the typical consumer and the typical saver is large enough to justify more attention and perhaps to justify different models for the two groups.

Section VI concludes the paper. We begin by discussing the destructive implications of the results for representative consumer approaches to the study of asset pricing, economic growth and economic fluctuations. We then suggest some constructive implications of the results for understanding international differences in saving rates, takeoffs of economic growth and the effects of tax policies. Finally, we suggest some directions for future research.

\section{International Evidence on Consumption and Growth}

The representative agent infinite horizon consumer model is the simplest and probably most commonly used model in studies of intertemporal issues. The Ramsey model (as we will refer to it throughout) provides the basis for the large body of work on consumption that has emanated from the seminal analysis of Hall (1978). The increasing popularity of this framework for analyzing intertemporal income and consumption behavior is suggested by the large literature surveyed in Campbell and Mankiw (1989). The focus of the research described there has been on the relationship between short-run fluctuations in consumption and income and on the rature of substitution between present and future income. Here we focus instead on longer term predictions of the theory.

In the commonly used constant relative risk aversion formulation, 
solution of the model gives rise to the first order condition for a consumer operating under certainty:

$$
\dot{c} / c=\sigma(r-\delta)
$$

where $\sigma$ is the elasticity of substitution of consumption, $\delta$ is the consumer's subjective discount rate and $f$ is the interest rate. Under uncertainty, it will continue to be the case that the interest rate is a sufficient statistic for predicting consumption growth. In a world with a well functioning capital market that equates returns on the safe asset in different countries, the simple model of (1) predicts that consumption growth rates averaged over long time periods should be equalized around the world if tastes for present as opposed to future consumption do not vary across countries.' It certainly would not imply that consumption growth rates should bear any particular relation to income growth rates. We shall now argue that this prediction is obviously and dramatically falsified by the recent experience of industrialized economies.

We have gathered data on income and consumption for fifteen OECD countries for the period 1960-1985.2 Our sample includes all the major Western European economies, Japan, the United States, and Canada as well as all of the smaller economies for which relatively complete data was available for the entire period. We study the effects of low frequency

\footnotetext{
1 We comment below on the possibility that diffezences in tastes can explain our observations.

2 Because of data limitations we do not carefully distinguish durable and nondurable consumption as theory would suggest. Given that durables are a relatively stable share of consumption in the United States at least, we doubt that this has much impact on our results.
} 
variations by looking at differences both across countries and across

different time periods in individual countries. For these comparisons, the issues of measurement and time aggregation that have been discussed in the literature on the time series properties of consumption are not very important. In order to highlight the strength of the patterns in the data we present them graphically.

Figures la-ld document a stylized fact that any theory of consumption should account for: At low frequencies there is near perfect equality between consumption growth rates and income growth rates. When consumption growth rates are plotted against income growth rates the result is almost precisely a $45^{\circ}$ line. While Eigures $1 \mathrm{a}, 1 \mathrm{~b}$, and lc document this fact looking across the entire 1960-1985 period and two different subperiods. Figure 1d compares the change in income growth with the change in consumption growth between the 1960-73 and 1980-85 periods. We choose these periods so as to avoid the difficulty of assessing when during the 1970 s expectations became entrenched that the productivity slowdown would last. Again the result is close to a 45 degree line.

While we have used GDP growth in these comparisons rather than the disposable income measures that would be more appropriate on some views, this and other measurement issues cannot be important. It is easy to see that the consumption growth-income growth regularity has to hold up using almost any measure. Suppose that over a 25 year period a country's saving rate changed by 15 percentage points. This would only alter its consumption growth rate by .6 percentage points, a rather small difference compared to the spread of growth experiences illustrated in Figures la and 1b. In fact, the striking thing about saving rates, whether measured on a private or a national basis, is their stability through time. Comparing 
the saving rates of the countries in our sample before and after 1973, no country experienced a change of more than 58 in either its private or its national saving rate. ${ }^{3}$ This compares with a range of saving rates across countries of over ten percent.

Returning now to the Ramsey model, Eigures la-ld appear anomalous in light of the model's implication that the expected rate of growth of consumption should be the same across countries, and should be unrelated to the rate of growth of income. We therefore consider in turn whether income surprises, imperfect capital markets, or international differences in tastes can explain the consumption/income parallel within roughly a Ramsey Eramework.

Income Growth Surprises

One possible objection to direct tests of the independence proposition arises from the possibility that differences in income growth over time were largely unexpected. If the consumer receives information about present or future income she will adjust her level of consumption discontinuously to be consistent with her new intertemporal budget constraint. From this new level the proposition will again apply, but if we calculate consumption growth between the period before the information arrived and the period after it arrived we will not observe a growth rate of $\sigma(r-\delta)$. Moving from the abstract to the concrete, this point would be important if, for instance, Japan's continued growth over the postwar period constituted a succession of pleasant surprises which successively caused Japanese consumers to adjust consumption upward in accordance with

3 We use both private and national saving measures in order to avoid taking a stand in the Ricardian equivalence debate. 
their new, surprisingly higher, lifetime income.

A first bit of evidence on the plausibility of this scenario is given by Eigure 2, which plots DRI's projected income growth for our sample of fifteen countries from 1988 to 2000 against their actual growth rates over the period 1976-1988. The figure illustrates that there are major differences in expected rates of growth of income across countries. Furthermore, expected future income growth is clearly correlated with past income growth. This suggests that the simplest version of a "surprise" theory, in which any deviation from the average growth rate is unanticipated, is very hard to sustain.

Table 1 presents some more formal tests of the idea that the close international correlation between income growth and consumption growth reflects the effects of income surprises. We estimate an international cross section relating consumption growth to measures of expected income growth formed on the basis of past income growth. Each equation includes year dumies so the identifying variation comes from variations across countries in consumption growth and lagged income growth. The results using measures of income growth over long past periods suggest a nearly one-to-one relationship between expected income growth and consumption growth ${ }^{4,5}$

The results using only a single lag of income growth are less strong.

\footnotetext{
4 Note that this test differs from the popular Hali-style tests by focusing on lowfrequency measures of income growth rates like the geometric average over the previous five years rather than very high frequency variasies ilke previous quarter's income growth. If we believe there is long-term dependence in growth rates then this is an appropriate variable to use as a proxy for expected current and future growth. 5 we recognize that the previous discussion does not fully address the implications of uncertainty, because the model which produces (l) is a perfect certainty model. We address the implications of a model which incorporaces important uncertainty below.
} 
However, this is accounted for by the fact that lagged income growth over a long period is a better predictor of contemporaneous income growth than is lagged income growth over a short time period. When past income growth is used as an instrument for expected income growth all specifications suggest a very strong relationship between consumption growth and income growth. Imperfect Capital Markets and Different Interest Rates Consider a set of independent closed economies with different rates of exogenous productivity growth. Then theory predicts that each would converge to a steady state with consumption growth equal to income growth. The first order condition (1) would be satisfied in each country because of differences across countries in the steady state real rate of interest. More rapidly growing countries would have higher real interest rates. It is possible therefore that the close correlation between consumption growth and income growth is a consequence of imperfections in the international capital market. In this case, one would expect to observe a close relationship between consumption growth rates and rates of return.

Figures 3a-d illustrate, however, that there is essentially no evidence looking across countries that differences in consumption growth rates across countries are explained by differences in real interest rates or other proxies for ex ante returns. This point may be seen most easily by comparing the United States and Japan. It is almost inconceivable that a plausible measure could be found on which ex-ante returns were higher in Japan than in the United States in recent years. This evidence is reinforced by Eigure $3 e$ which asks whether changes in consumption growth rates in different countries between the pre-1973 period and the post-1980 period are predicted by changes in real interest rates. Perhaps surprisingly the countries with the greatest declines in consumption growth 
rates had the smallest declines in real interest rates.

The point that differences in average returns across countries cannot account for differences in consumption growth can be made another way. The range of consumption growth rates in our sample of countries is 3.4 percent. Most estimates of the intertemporal elasticity of substitution put it at below .25 . Even taking the high rate of .25 , and assuming that differences in consumption growth rates were perfectly explained by differences in rates of return, the range of rates of return would have to be 13.6 percent. Persistent differences in safe rates of return of this magnitude over a 25 year period are implausible on even strong views about world capital immobility.

In an influential paper Mehra and Prescott (1985) have raised questions about the ability of the representative consumer model to account for the risk premium between debt and equity. This problem is deepened by the apparent absence of correlation between safe interest rates and consumption growth rates across countries. It appears that any successful attempt to rationalize differences in consumption growth rates across countries with fairly similar interest rates would involve postulating a high intertemporal elasticity of substitution. This deepens the difficulty of accounting for the equity risk premium.

Variation in Tastes

One potential channel for reconciling the Ramsey formulation with these facts is to assert that discount rates $\delta$ differ across countries. If the production technology is of the "Ak" variety discussed by Barro (1989) differences in $\delta$ would also be associated with differences in steady state growth rates. The same would be true in endogenous growth models relying 
on increasing returns of the type developed by Paul Romer (1986) and others. Even if there were diminishing returns, one would expect that low $\delta$ countries would grow more rapidly while in transition to their steady states (assuming countries started with equal, below steady state capital intensity).

We are skeptical that differences in growth across countries and across time primarily reflect taste differences. It seems very implausible to suppose that the primary reasons for the worldwide slowdowns in economic growth rates between the $1960-73$ and $1980-87$ periods was a taste shock reflecting increased impatience. Yet, since the growth rate of consumption in (1) depends only on tastes and the interest rate, a simultaneous worldwide increase in impatience would be necessary to account for the simultaneous slowing of consumption and income growth.

Even returning to the cross-country consumption growth-income growth relation, the "tastes" theory has a problem. If differences in tastes were a dominant explanation for differences in growth rates there should be a strong tendency for low $\delta$ (fast growing) countries to lend to high $\delta$ (slow growing) countries. As Table 1 makes clear, this tendency is not apparent in the data. No matter how the data are disaggregated by time there is apparently little or no correlation between trade balances and growth rates.

Note finally that unless an extremely high value of $\sigma$ is selected, enormous differences across countries in subjective rates of discount are needed to account for the wide range of observed consumption growth rates. Conclusion

We conclude that there do not appear to be plausible ways of squaring 
the independence proposition with our facts. While some story involving both variations in $r$ and in $\delta$ could be used to account for differences in consumption growth across countries, the problem of explaining why they are so nearly equal to differences in income growth would remain.

\section{The Iife Cycle and the consumption/Income Parallel}

As a matter of logic, the life cycle hypothesis is consistent with both the stylized fact that consumption and income growth rates are equated across a sample of countries and the fact that saving and growth rates are positively correlated. T'o see this think of a very simple life cycle model where individuals seek level consumption over their lifetimes. Even though individuals would have level consumption over their lifetimes regardless of their income growth rates, it will nonetheless be true that in steady state total consumption will grow at the same rate as total income. This is because the gap in lifetime income between old and young generations is greater in rapidly than in slowly growing countries.

Consider the modern life cycle hypothesis's explanation of the equality between consumption and income growth rates across countries with different growth rates. The essence of the theory (assuming common tastes worldwide and the irrelevance of rate of return differences) is that the rate of growth of consumption for all individuals is the same in all countries. (Implicitly we are assuming rational expectations rather than the myopic expectations assumed by Modigliani in some early statements of the life-cycle hypothesis.) Countries differ in their consumption growth rates only because of the differential effect of the continuous replacement of old, lifetime poor individuals by young, lifetime rich ones.

This argument has two essentially equivalent testable implications. 





consumption profiles are provided in Figure $4 \mathrm{~b}$. We have carried the profiles only up to age 65 because of concern that measures of the consumption of the aged are distorted in some countries by the tendency of the poorer elderly to move in with their children.

The results are at odds with life cycle hypothesis, since the profiles look quite similar across countries. The similarity of these profiles means that there is no evidence that old people in the slowgrowing countries have relatively higher consumption than those in the fast-growing countries. To take a specific example, the profile is more positively sloped in Japan than in the United States, exactly the opposite of what the theory would predict given Japan's much more rapid growth rate. Norway, which has also grown relatively rapidly, also has relatively higher consumption among the aged than the United States. Deaton (1989) using a sample of LDC's age-consumption profiles reaches conclusions similar to those reached here.

This comparison is very crude. But it is instructive to observe how large the differences in age-consumption profiles predicted by the theory would be. Over the 25 year period 1960-1985 per capita GNP in Japan grew at 5.2 percent as compared with 2.1 percent in the United States. Suppose that we take the Japanese steady state growth rate to be 4.0 percent and the US steady state growth rate to be 2.5 percent. Then the lifetime income of 30 year olds in Japan should be 3.94 times the lifetime income of 65 year olds, compared with a ratio of 2.37 in the United States. This is a difference equal to more than 1508 of the income of the average 65 year old. It is large enough that one would expect it to show up even in our crude measures of age consumption profiles. 7

7 Given the large differences in lifetime income between cohorts it is also 
What about the experience of individual cohorts? The longitudinal evidence that we would like to have to answer this question is not available. However, evidence discussed by Kotlikoff and Sumners (1981) for the United States and by Ando and Kennickell (1987) for Japan suggests that the shape of age-expenditure profiles is quite stable through time. Figures $5 a$ and $5 b$ for these two countries confirm that between the dates for which we have specific data the profiles have been fairly stable. If we make the stability assumption for all the countries in our sample it is possible to trace the consumption of individual cohorts by using data on aggregate consumption and the age structure of the population. If $c_{i}$ indicates the relative consumption of people in age group $i, p_{i t}$ indicates the number of people in this age group in year $t$, and $y_{t}$ is total real personal consumption in year $t$, then we calculate a scaling factor st from the equation:

$$
y_{t}=s_{t} \sum_{i} c_{i} p_{i t}
$$

Using the scaling factor $s_{t}$ we calculate real consumption of people of age group $i$ in year $t, c r_{i t}$, from $c r_{i t}=c_{i}{ }^{3}$. The results are shown in Figure 6. Not surprisingly given our results so far, this technique indicates that individuals in fast-growing countries like Japan have enjoyed much more rapid growth in consumption than individuals in slowergrowing countries like the United States. How much more rapid? Given that the cross-section profiles are very similar across the whole range of countries in Figure $4 \mathrm{~b}$, it follows that none of the difference in surprising under the life cycle theory that the consumption of 30 year olds is not much greater than the consumption of 65 year olds in both countries. 


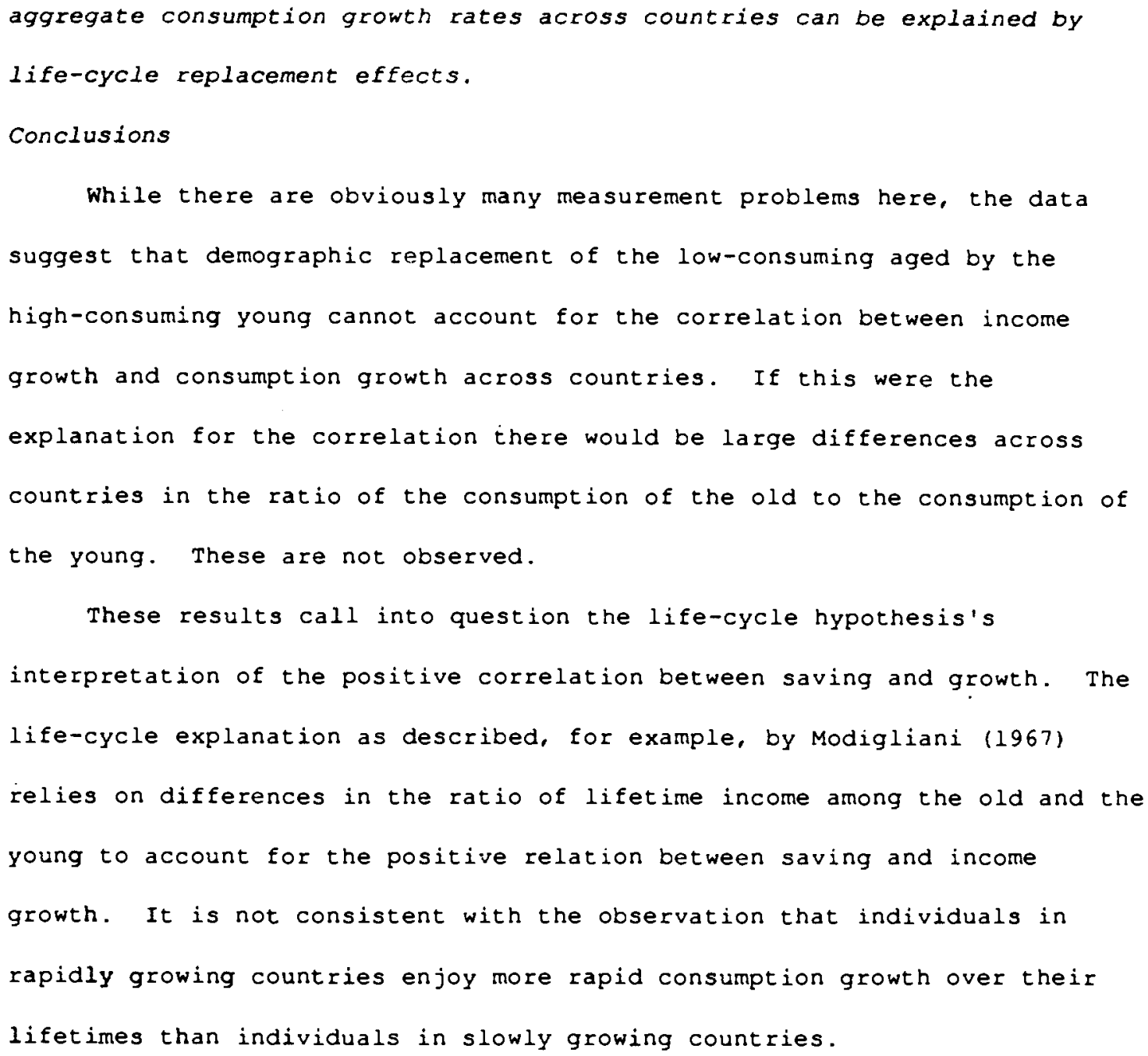

\section{Tests Using Individual Data}

Section I demonstrated that consumption growth has been very closely related to income growth across both countries and time and argued that this was not consistent with the standard Ramsey model. Section II argued that the consumption/income parallel could not be explained by life-cycle considerations. This leaves two classes of explanations for the apparent international association of consumption growth and income growth. A first 
possibility is that because consumers are myopic or liquidity constrained or operate on the basis of rules of thumb, consumption and income are strongly associated. A second possibility is that some common cause of both rapid income growth and rapid consumption growth operates across countries.

In an effort to distinguish these possibilities, this section uses information on income growth and consumption growth for individuals in different occupations and with different educational backgrounds. Liquidity constraints, myopia, or the like would be expected to create an association between age-consumption and age-income profiles across different occupations. On the other hand theories of growth that might apply at the international level would not imply that individual age-income and age-consumption profiles should move together.

Anecdotal evidence about sports stars and medical students suggests that consumption is closely tied to current income, but for a more formal test we turned to the Bureau of Labor Statistics Consumer Expenditure Surveys of 1960-61 and 1972-73. These studies, originally done for the purpose of calculating consumer price indices, contain detailed expenditure and income accounts for a large representative sample of households 113,000 in $1960,20,000$ in 1972), and so are an ideal source for comparing income and consumption of households at different ages. For our income measure we took the total after-tax income of the household. We experimented with several definitions of consumption and expenditures, ranging from total expenditures of the household (including payments for social security and prearranged pension plans) to just consumption of nondurable goods. The consumption measure below does not include payments for social security, 
private pensions, or home mortgages, but does include gifts and contributions to private charities and to other households, as well as insurance premia.

Figures $7 \mathrm{a}, \mathrm{b}$ and $8 \mathrm{a}, \mathrm{b}$ present mean income and consumption profiles for the nine occupational groups and the five educational levels that could usefully be distinguished with the CES. ${ }^{8}$ The data's suggestion that saving for almost all groups increased between the first and second survey is almost certainly a consequence of changes in measurement procedure. What is more interesting is the figures' apparent refutation of the simple Iife cycle/permanent income view that the shape of the path of income should not have an effect on the shape of the consumption path. In life cycle terms, these graphs indicate that people in occupational or educational groups with income peaks late in life do not borrow significantly against those future earnings in order to finance higher consumption when they are young. Conversely, people with income peaks relatively early in life do not appear to save much in anticipation of lower future income. These observations appear inconsistent with life cycle theory.

It is possible to imagine some combinations of circumstances which can explain some of the apparent correlation above while remaining roughly within a life cycle framework. For instance, suppose that each cohort in a category consumes its permanent income and that the differences in income

8 The unused occupational groups were retired people, noncesponses, and others. The unused educational group was "none, nonresponse, or other". The figures grouped by occupation are in order of increasing variance, so more credibility should be ascribea to inferences arawn from figures near the top of the page than those near the bottom. The difference in variance across educational groups was substantially less lthe groups are closer in size) so the figures grouped by education are ordered by increasing educational level. 
across categories and age groups are the result of idiosyncratic shocks to cohorts. Then we would observe the pattern that the income and consumption of households of any given age within a category would be closely related, as we see in the figures. This explanation works, however, essentially by denying any element of predictability in income profiles. But at least across educational categories there is a very strong resemblance of the age/income profiles in the 1972-3 CES to those in the 1960-1 CES - surely a strong refutation of the "no predictability" hypothesis. And informally, we surely believe that people with college and postgraduate educations can expect higher wage growth over their lifetimes than those with only grade school educations, so that there is surely some degree of predictability. Although the degree of similarity of 1960 and 1973 income profiles is smaller across occupations than across educational categories, it is still the case that several occupations, particularly professionals, managers, operatives, and unskilled workers, have quite similar, and thus presumably predictable, profiles in the different years.

The calculations here do not take account of changes in family composition. By calculating consumption on an equivalence scale basis it is possible to create consumption profiles that do not follow estimated income profiles. But it is not clear what this proves, since total consumption spending does follow income. More relevant is the observation that there do not appear to be large differences in average family sizes at different ages among different educational and occupational groups. While the issue deserves further research, our tentative conclusion is that parallel movements in income and consumption cannot be explained by family size considerations. 
Another explanation of the consumption/income parallel was provided by Ghez (1969). Using the 1960 CES, Ghez prepared a figure for all consumers similar to our Figures 7 and 8 for subcategories of consumers and sought to explain the observed close correlation between income and consumption using a "family production function" model of the type advocated by Becker (1965). Suppose, for example, that utility is a function both of consumption $c$ and hours of leisure h. Suppose further that, because of the accumulation of experience or other human capital, hourly wages grow over the life cycle. Then individuals will have an incentive to work the longest hours when they are most productive, late in life. But this extra work takes away leisure time, giving the consumer an incentive to consume more time-substituting goods. The consumer will therefore be observed consuming more during those periods of life when he works most and earns the most income. To be more specific, this model would suggest that busy executives late in life would be more likely to have a maid to do housekeeping chores and more likely to send out their laundry than young people with (presumably) more time on their hands.

The Ghez model seems unlikely to be a satisfactory explanation for the close consumption/income parallel observed in Figures 7 and 8 for several reasons. First, it is not even obvious that consumption and hours are substitutes rather than complements. With more leisure time one can engage in expensive activities, such as foreign travel, that may not be possible at all at in busier periods of life. Ghez himself makes the point that if time is very valuable one may eat more fast food (presumably inexpensive) and fewer elaborate meals out (presumably expensive). Further, even if we accept that consumption and hours are substitutes, the Ghez model only makes predictions about the sign of the relationship 


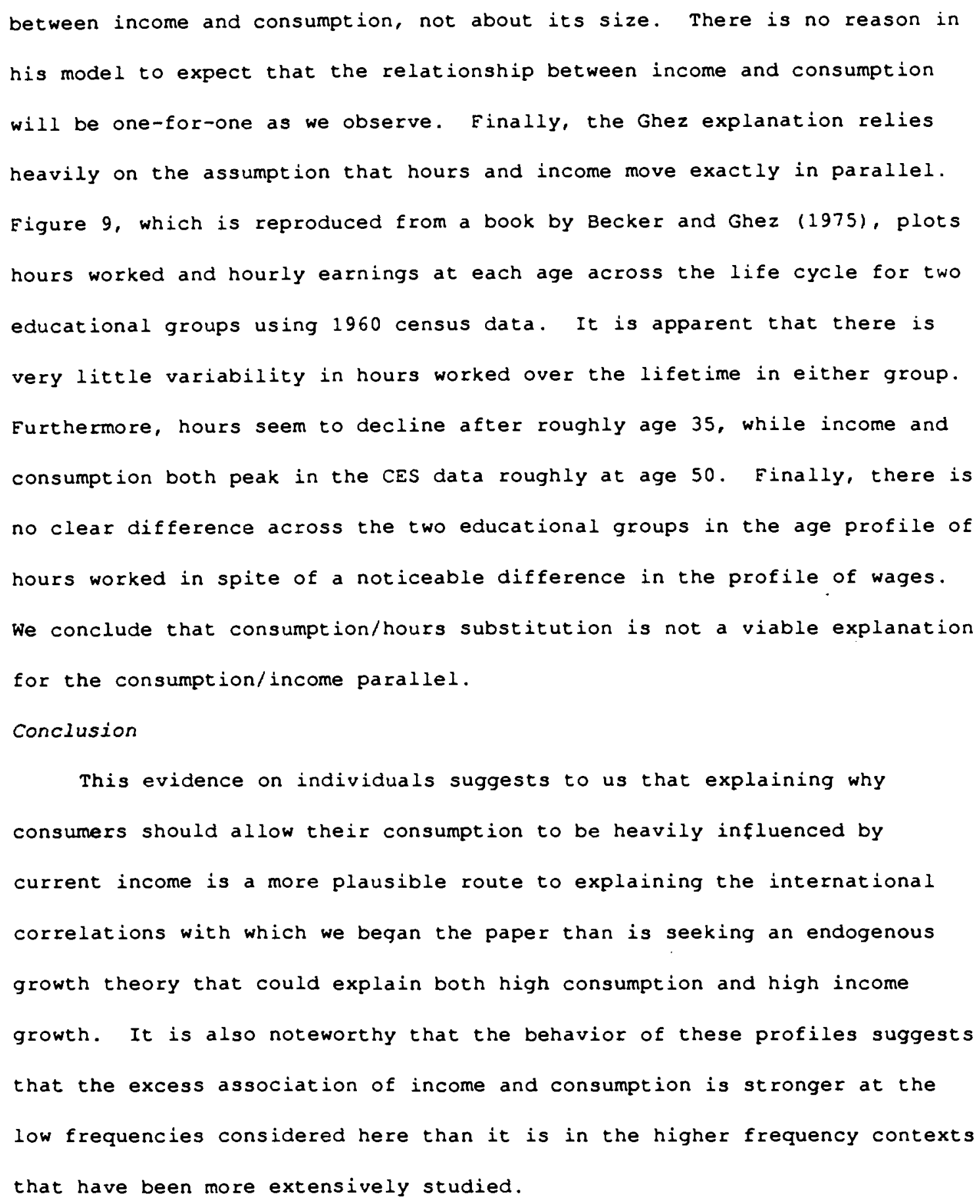







productivity slowdown focuses on its effects on consumers in different age groups. A decline in growth reduces expected future income by much more for young consumers than for older ones, and not at all for those who have retired. Whatever happened to overall saving, one would expect to observe a tendency for the relative saving rate of the young to rise following the productivity slowdown if consumers were farsighted. This tendency should have been reinforced by declining fertility. It is borne out only to a very slight extent in Figure 12. (Again, because of changes in measurement procedures, nothing can be inferred from the position of these profiles, only their shape.) This finding is perhaps not so surprising given that the shape of the age-saving rate profiles in Figure 12 are not really consistent with the predictions of the life-cycle theory in the first place.

Information on the shape of occupational income profiles can also be used to test the life-cycle theory. It predicts a tendency for those in occupations where income can be expected to rise rapidly to save less than those in occupations where income can be expected to rise slowly. The profiles from Figures 7 and 8 can be used to calculate a ratio of future income to current income for young people in different occupational groups and the results can then be compared with observed saving rates.

Eigures $13 \mathrm{a}$ and $13 \mathrm{~b}$ plot, for each occupation in 1960 , the ratio [future income/current income] against the saving rate of young people in that occupation, where "future income" is defined as the sum of income for people age 30-65 and "current income" is the sum of income for people age 25-29, and "young" refers to people in the age group 25-29. The slope of these lines should be strongly negative because high-future-income 


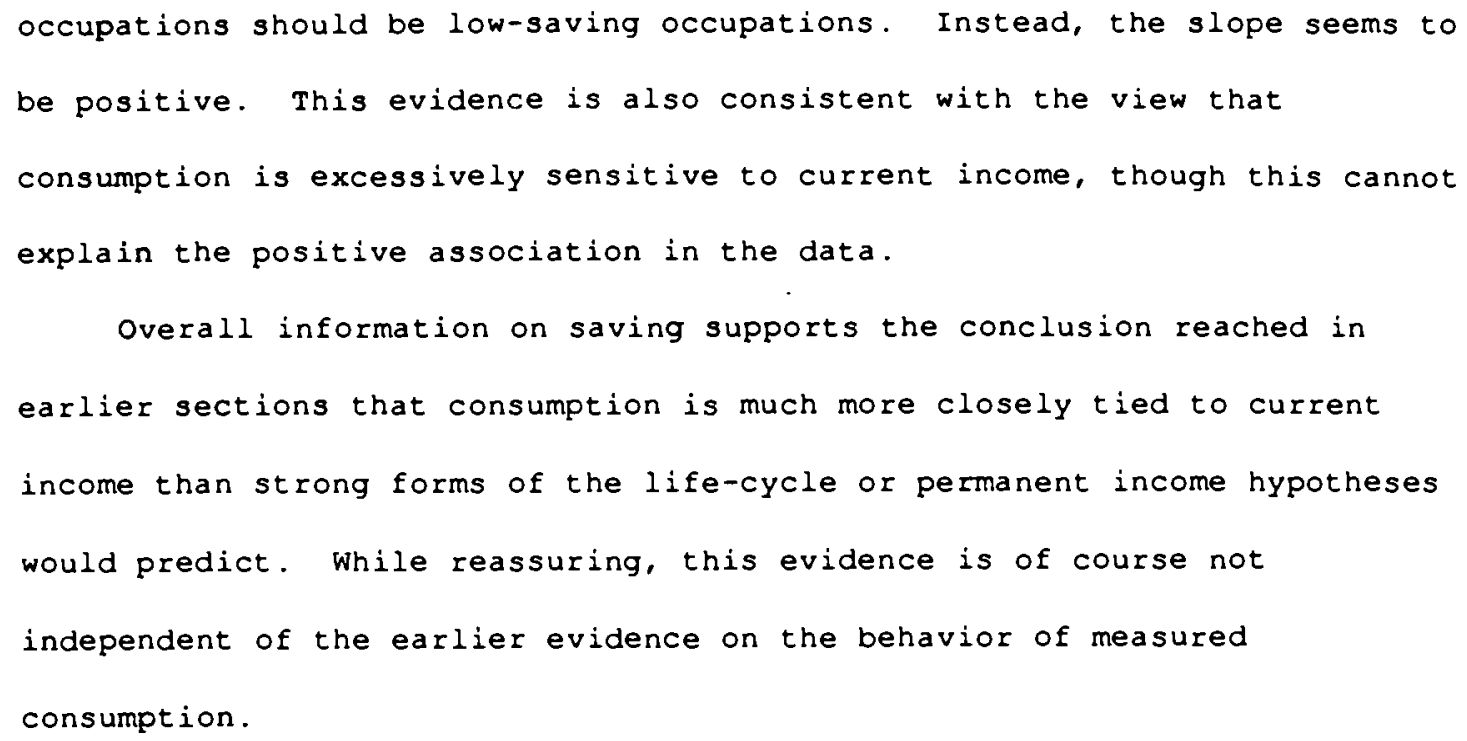




$$
\dot{c} / c=\alpha(\dot{y} / y)+(1-\alpha)\left(\dot{c} \star / c^{\star}\right)
$$

In order to account for the unit slope observed in Figure 1 it is necessary to postulate that $\alpha=1$ so that the entire population is liquidity constrained. This assumption robs the permanent income theory of any content. In addition, it leaves unanswered the unquestion of where savings come from. Of course it is also contradicted by all of the evidence supporting the permanent income hypothesis. The challenge is finding a theory that can account for the apparent absence of pervasive liquidity constraints or myopia in high frequency tests but can still account for our low Erequency facts.

However, the possibility that most consumers act as if they were liquidity constrained or expected to be in the future should not be ruled out. Studies such as Campbell and Mankiw (1989) which seek to estimate the fraction of rule-of-thumb or liquidity constrained consumers by applying time-series techniques are likely to understate it for three reasons. First, the specification adopted assumes a restrictive form of liquidity constrained behavior. It would be more difficult to demonstrate conclusively the existence of an economically significant set of permanent income consumers if the myopes were assumed to follow a rule in which consumption responded to income and its lags. Second, the assumption that liquidity constrained consumers spend a fixed fraction of their income on non-durable consumption rules out the possibility that these consumers cut durable spending disproportionately when income declines. If this is in fact the case, standard methods will understate the liquidity constrained 
fraction of the population. Third, most recent research effort has focused on the post-war period where income is close to a random walk. Delong and Summers (1986) present evidence that in the pre-War period when income fluctuations were more transitory the fraction of liquidity constrained consumers was greater.

In spite of the considerable evidence that liquidity constraints are important, the assertion that people spend their incomes is not a rich enough theory of saving. We are attracted by Angus Deaton's (1989) view of savings as a "buffer stock" for contingencies. As he argues, situations where consumers are liquidity constrained and where they are unwilling to borrow because of the possibility that this would force their subsequent consumption to decline sharply in the event of bad news are likely to be operationally very similar. The buffer stock view has the appeal of predicting (or at least labelling) the consumption smoothing which goes on at high frequency but not implying that consumption smoothing should go on over long horizons. It also has the potential to explain the observed correlation between saving and growth. If consumers desire las financial planners recommend) a buffer stock equal to a certain number of months' income, saving will be greater for consumers with rapidly growing incomes than for those with slowly growing incomes. Essentially, the accelerator mechanism will create a positive growth-saving relationship.

Table 3 presents some empirical evidence drawn from panel data on tax returns for the period 1979-1984 which supports the buffer stock idea. For persons under and over 65 , it presents estimates of the fraction of people, fraction of labor income, fraction of total income, and fraction of interest and dividend income going to persons with less than $\$ 100$ in 


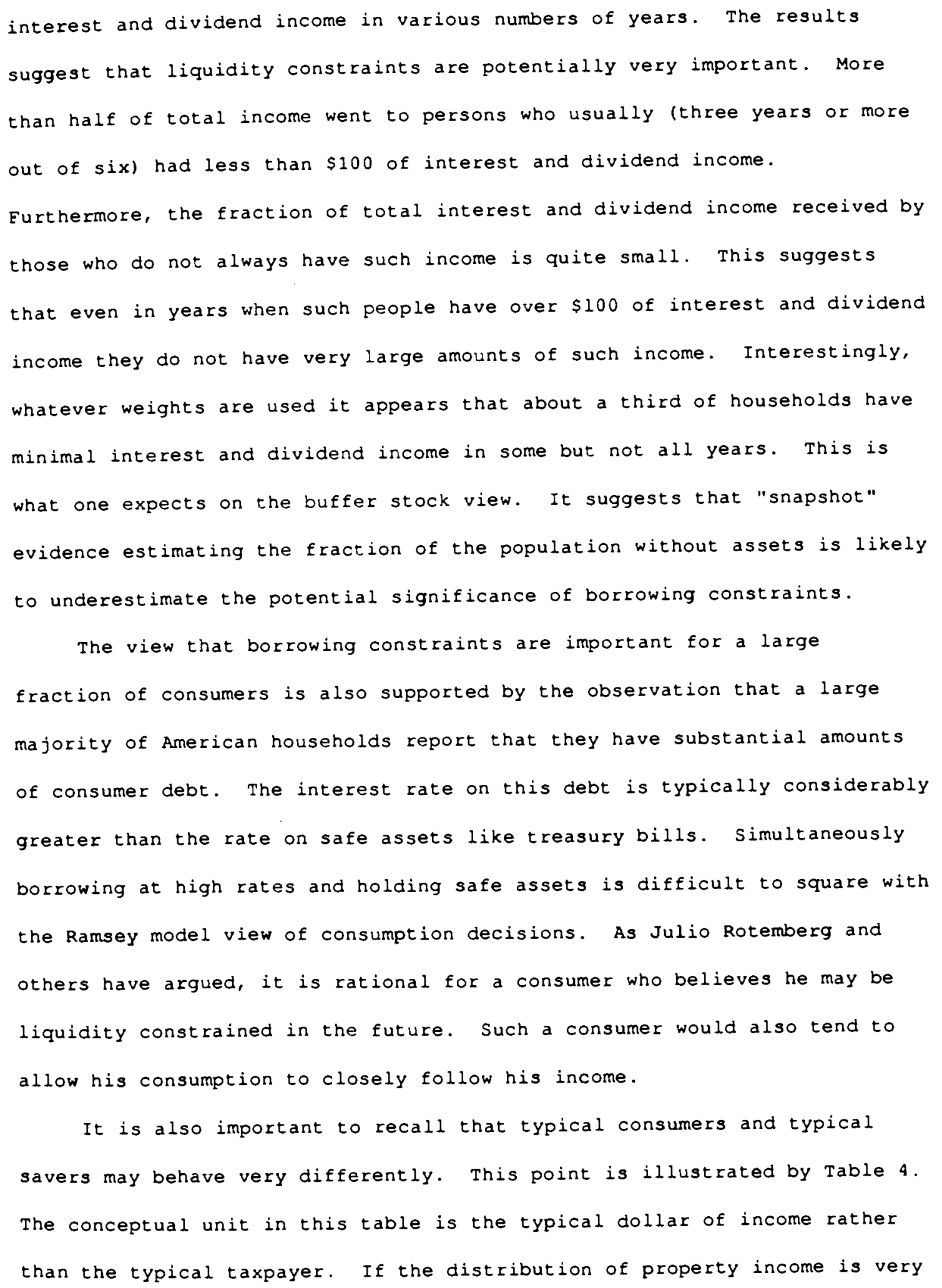


unequal we should expect the median or mean dollar of property income to accrue to a person with a very large amount of such income. This is exactly what the table shows. Although the median dollar amount of interest and dividend income was $\$ 185$, the median dollar of such income went to someone with property income of $\$ 16,100$. Furthermore, although the mean amount of interest and dividend income was $\$ 2755$, the mean dollar went to a taxpayer earning $\$ 46,533$ of property income. (See appendix for details).

The numbers become even more striking when we use assumed rates of return to convert statements about capital income into statements about liquid assets (see appendix for details). When we do this we discover that the median dollar of (estimated) assets is held by a person holding $\$ 212,415$, and that the mean dollar is held by a person with nearly a million dollars of liquid assets. The general picture of extreme inequality in the distribution of wealth painted by these numbers is borne out by an analysis of some evidence from the Federal Reserve's Survey of Consumer Finances in a recent paper by Avery and Kennickell (1988). The SCF allows a direct calculation of net saving via a comparison of families" net worth in 1983 and 1986. In Table 12 the authors estimate the fraction of aggregate positive saving between 1983 and 1986 that was done by the members of each 1983 wealth decile. They estimate that nearly 70 percent of all the positive saving between 1983 and 1986 was done by families in the top 1983 wealth decile. Using crude smoothing techniques (see appendix), we calculated that the median dollar of saving was done by a family roughly at the $94 \mathrm{th}$ percentile in the wealth distribution. Smoothing again, we estimated that a person at the 94 th percentile in the 
1983 wealth distribution had $\$ 661,000(1988$ \$) of net wealth. This compares with an estimated median 1983 net wealth of $\$ 46,800(1988 \$)^{9}$ Again it would appear that wealth and saving are extremely unequally distributed.

Taken together, this evidence along with Tables 3 and 4 suggest that there are two kinds of consumers. The great majority of consumers are liquidity constrained and have only small amounts of liquid assets, which they keep as a buffer against uncertainty. A small minority of consumers, however, have very substantial assets and are not liquidity constrained. These wealthy consumers are the source of most of the net dollars saved in the economy.

Conclusion

The broad picture painted above suggests that focusing separately on two different models, one for the liquidity constrained majority of consumers who save little outside of housing equity and one for the small but wealthy minority who seem to do most of the saving, will yield more empirical success than continuing to work with a single model postulating identical unconstrained consumers. These are not new ideas: in arguing for a typically short horizon, Milton Eriedman (1957) observed "..The appropriate definition of the permanent component [of income] is a period of three years or slightly longer. This is the same as the conclusion reached earlier from [different] data on urban families. It is also consistent with the time series data. It is encouraging to find such a close agreement in the precise definition of permanent components suggested by three independent bodies of data." And the idea that accumulation is

\footnotetext{
9 Note that these wealth estimates include housing equity, which accounts for the discrepancy between the estimated median wealch here and in Table 4.
} 
chiefly an activity of the already wealthy goes back at least to pareto.

\section{vI Conclusions}

Recent studies of consumption behavior have tested increasingly subtle implications of the life cycle/permanent income hypothesis using increasingly sophisticated time series techniques with increasingly ambiguous results. Many existing estimates suggest that at least a large fraction and possibly all of consumption is done by optimizing non-myopic non-liquidity constrained consumers maximizing individualistic utiity functions with long or infinite horizons. We believe this conclusion is not correct. It seems to us that the wide variety of evidence presented here is much more robust to the possibility of measurement or specification error than the numerous complex econometric tests that have been performed. We regard our evidence as decisively refuting the low frequency predictions of standard intertemporal theories.

As we emphasized in the introduction, the evidence here is generally consistent with the life-cycle and permanent income hypotheses as they were originally advanced. Indeed, Milton Eriedman explicitly rejected the idea that consumers had horizons as long as a lifetime in discussing the permanent income hypothesis. And Modigliani relied on myopic expectations in some early development of his theory. What is decisively rejected here is the modern representative consumer versions of these theories, not the core idea that people seek to smooth consumption. While the evidence here does not undercut the usefulness of the lifecycle and permanent income theories in explaining some broad features of consumption behavior, it does cast serious doubt on modern uses of these 
theories which take the idea of a representative forward looking consumer very seriously. The absence of any relation between rates of return on a variety of assets and consumption growth rates across countries makes us skeptical of the use of consumption information in explaining risk premia on different capital assets. The absence of any clear tendency for consumption to respond to expectations of future income growth leads us to doubt that models which assume consumers optimize over long or infinite horizons will give very good predictions about the effects of various tax changes. And we suspect that those concerned with modelling the determinants of income growth should build in a different consumption function than the one suggested by the Ramsey model. Finally, we note that a major claim of real business cycle theorists is that their models on the basis of non-cyclical phenomena. It does not appear that the representative consumer approach used in most real business cycle models is consistent with low frequency evidence.

We argued in section $V$ that Deaton's notion of the saving of the typical consumer as a buffer stock to smooth consumption over short horizons and to prepare for temporary sharp declines in income was consistent with both the evidence usually cited in favor of life-cycle permanent income theories and our low frequency evidence. We argued further, however, that although the buffer stock model may describe the typical consumer well, it may not accurately describe the typical saver because saving and wealth are extremely unequally distributed. Further research is needed to determine how the behavior of the typical consumer differs from the behavior of the typical saver.

Even though it may not apply to all consumers, we are attracted to 
the buffer stock model for several reasons. It provides a natural explanation for the correlation between saving and income growth both across countries and across occupational groups. If consumers desire to hold a cash reserve equal to a certain number of months of income, they will have higher saving rates the more rapid is their income growth. This notion raises a number of interesting possibilities for the growth process. If, as recent studies have argued, steady growth rates are increasing functions of saving rates, and if as we have just suggested saving rates are positive functions of growth rates, there is a clear possibility of multiple equilibria. This idea might be relevant to the experience of nations like Taiwan and Korea where actual and expected growth rates have increased sharply and at the same time that saving rates have soared.

The buffer stock model, if correct, also has implications for certain tax policy issues. In the United states there has been considerable controversy about the efficacy of IRAs and other savings vehicles. Critics allege that individuals transfer money from one account to another to realize tax benefits without doing any incremental saving. To the extent that, because of its illiquidity, IRA saving is not a substitute for buffer stock saving, it may be incremental even for households which have liquid assets.

Our future research in this area will proceed in two directions. First we need to refine our knowledge about the behavioral differences between the typical consumer and the typical saver. Second, we will try to develop models that can explain the differences between typical consumers and typical savers, and models that are consistent both with the high frequency evidence that some consumption smoothing exists and the low 
frequency evidence that consumption growth tracks income growth. Although a single unified model may be desirable as an eventual goal, it may turn out to be more fruitful in the meantime to pursue separate models to explain the consumption/income parallel and the consumption/saving divergence. We hope that this multifaceted approach will eventually succeed both in explaining international differences in saving rates and in making predictions about the response of saving to policy changes. 


\section{Appendix: Data Sources and Methods}

This appendix describes the sources and methods used to prepare the data charts and tables of the paper. We proceed roughly in the order in which the data appear.

OECD Data on Income, Consumption, and Interest Rates

OECD data come from the DRI COECDNIA, CIME and COECDMEI databases. Data for most countries for most series begin in 1960 . Gross Domestic Product is given by the series VAGDPA, personal consumption is given by AGPC, real personal consumption by AGPCR. We derived the CPI deflator and hence inflation rates by dividing AGPC/AGPCR (for some reason the direct data on deflators is less complete than this indirect source). population figures come from the eIME database, series 1992 . Trade balance data were taken from the CIMF database series 177 ac\&d or the nearest existing equivalent. The fifteen countries which appear in most of the figures are: the U.S., the U.K., Austria, Belgium, France, West Germany, Italy, Norway, Switzerland, Canada, Japan, Finland, Greece, Australia, and Sweden.

For short run interest rates we generally used the rate of return on three month T-Bills, except in Italy where the only series was for $\mathbf{s i x}$ month T-bills (with a few missing observations which we filled from other interest rate series), and Erance and Germany where we used call money rates because there was no three month $T$-bill data before the early eighties. The other rate of return data are courtesy David Cutler, who calculated them from the Morgan Stanley Capital International Perspective. 


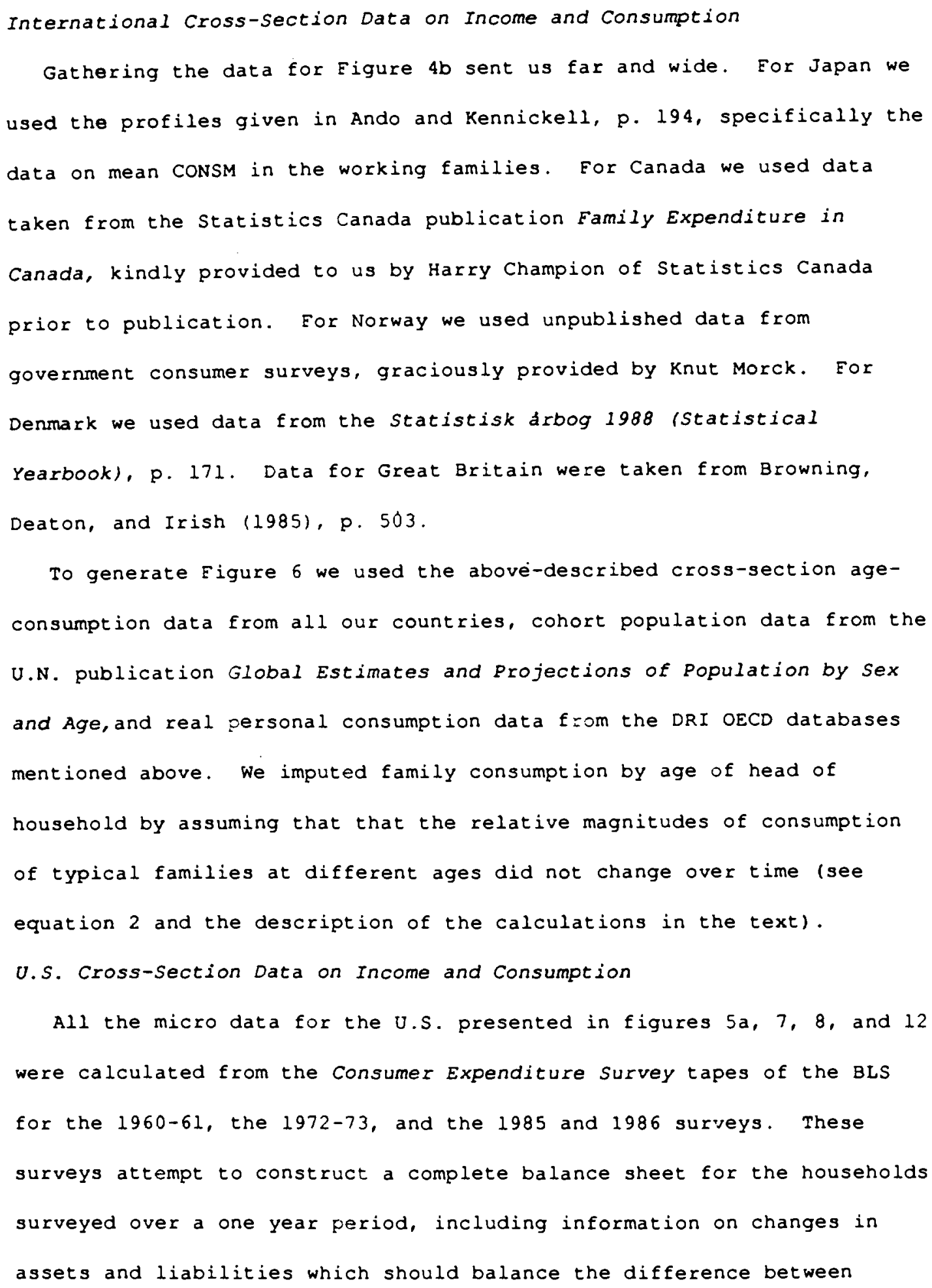


income and consumption. Fortunately the definitions of variables have not changed much between the surveys so we are able to calculate income: and consumption measures that should correspond over time. The 1960 survey, however, differed from the later surveys in at least two respects. First, each household was interviewed only once, at the end of the survey year, and asked to recall income and expenditures for the preceding year. In the later surveys each household was interviewed quarterly for five quarters in a row and asked about consumption over the preceding three months. Second, in the 1960 survey the interviewers made a greater effort to ensure that the family balance sheets actuaily balanced, so that if income exceeded consumption by $\$ 1000$ the interviewer tried to make sure that net assets rose by $\$ 1000$. There was less emphasis on such balance in the later surveys.

The figures result from straightforward calculations from the 1960-1. 1972-3, and 1985 Consumer Expenditure Survey tapes. In all years our income measure was disposable income after tax, calculated in the earlier surveys by subtracting all taxes from the total income variable; disposable income exists directly in the $1980 \mathrm{~s}$ tapes so was not calculated. As our measure of consumption we took the variable called "current consumption expenditures" in the 1960 and 1972 surveys and added insurance premia and cash contributions/gifts. To construct the same variable from the 1980 s surveys we took the "total expenditures" variable and subtracted contributions to pensions, retirement funds, and social security. The 1972-3 survey presented a particular problem because income numbers below $\$ 2000$ or above $\$ 35000$ were not reported. By comparing means of our tape sample with means in the BLS's printed 
summaries of the 1972-3 CES, however, we were able to calculate the average income of the bottomcoded individuals as $\$ 973.18$ and the average income of the topcoded consumers as $\$ 54,942$. The disposable income figures were $\$ 897.14$ and $\$ 44,057$ respectively. For consumers whose income was top or bottom-coded we assumed that their income was equal to the average income of their group. A final adjustment to the 1972 and 1985 samples was necessary because a small fraction of the people did not provide complete information about income; these were excluded from the sample altogether.

The basic patterns presented here were robust to the few reasonable variations in calculation technique we could think of, which consisted of excluding people from the sample for various plausible reasons and of considering different definitions of consumption and income $(e \cdot \dot{g}$. nondurables consumption, pre-tax income, wage income, etc). Detailed charts for 1985 analogous to those from $1960-1$ and $1972-3$ were not presented for two reasons. First, the 1985 data seemed to have much higher variability. This is partly due to a smaller sample size labout half as large) and partly (we think) due to a new processing methodology devised by the BIS. Second, the occupational group classifications in the 1980s-series CES's are much less detailed, and occupations within each group seem less similar, than is the case with the 1960-61 and 1972-73 surveys.

Liquidity Constraints Tax Panel Data

The liquidity constraints tax panel is a random sample (based on primary taxpayer's social security number) of tax returns. It includes single and joint returns, but women drop from the sample when they marry and return when they divorce or widow. The sample was maintained for 
1979 to 1984 . Of the total set of tax returns in the data set, there were 5997 taxpayers with positive adjusted gross income in all six years. This is the sample we used in preparing Tables 3 and 4 . The calculations for the tables were performed by Daniel Feenberg of the N.B.E.R.

The procedure for estimating liquid assets from capital income was simple. To estimate the market value of the stock portfolio we took dividend income and divided by the dividend/price ratio on the stock market as a whole for the appropriate year. To estimate the dollar value of interest-bearing assets we divided by the average interest rate on interest-bearing assets and cash. The latter was estimated by taking total personal interest earnings from the NIPA and dividing by the sum of cash and interest-bearing assets taken from the Federal Reserve Board's Balance Sheets for the U.S. Economy. The latter figure yields interest rates in the 8-108 range, probably much higher than the actual interest rate on the typical dollar of interest-bearing assets and cash. overestimating the interest rate should cause us to underestimate associated wealth, however, so whatever error exists here biases our results against finding the extreme inequality in wealth that we do in fact find. A more better interest rate measur should only intensify our findings about inequality.

The rates used in these calculations are given below. The dividend/price ratios were taken from the Dow Jones-Irwin Business and Investment Almanac, 1986. 


$\begin{array}{lll}\text { Year } & \begin{array}{l}\text { Dividend } \\ \text { Price } \\ \text { Ratio }\end{array} & \begin{array}{l}\text { Average } \\ \text { Interest } \\ \text { Rate }\end{array} \\ 1979 & 5.47 & 7.8 \\ 1980 & 5.26 & 8.4 \\ 1981 & 5.20 & 9.4 \\ 1982 & 5.81 & 9.3 \\ 1983 & 4.40 & 8.8 \\ 1984 & 4.64 & 8.9\end{array}$

A brief word about the interpretation of the numbers in Table 3 is in order. Consider, for example, the part of the table concerning AGI for everyone excluding the elderly. We claim that the median AGI weighted by AGI is $\$ 38,537$. What this means is that if we were to sort all taxpayers by AGI and then to find the taxpayer such that the sum of the AGI's of the taxpayers with less AGI than his equals the sum of the AGI's of the taxpayers with more AGI than his, that taxpayer has an AGI of $\$ 38,537$. This is what we mean when we say that the median dollar of AGI goes to a taxpayer with AGI $\$ 38,537$. The meaning of the mean dollar of AGI weighted by is less intuitive, but can be understood by analogy with calculation of mean tax rates. Suppose we knew income and total taxes paid by a set of individuals, and we wanted to calculate the average tax rate on all the dollars of income in the group. Simply taking the average of the tax rates across individuals would be inappropriate because the tax rate on individuals with high incomes clearly has more influence on the tax rate on the average dollar of income than the rate on low-income individuals. The appropriate procedure is to take a weighted mean of all the tax rates, where the weights are given by the incomes of the individuals. By analogy, the 





the point at which saving below that point equals saving above the point. This is the point that defines the amount of saving done by what we call in the text the "median" saver. The procedure described above was repeated using Avery and Kennickell's Table 10 to produce a distribution of wealth by wealth decile and the resulting function was used to calculate the estimated wealth of someone at the 94 th percentile in the wealth distribution, the point that the previous function identified as being associated with the median saver. 


\section{References}

Ando, A. and Modigliani, F., "The Life Cycle Hypthesis of Saving:

Aggregate Implications and Tests", American Economic Review, Vol. 53. May 1963, pp. 55-84, and Vol. 54, Part I, March 1964, pp. 111113.

Ando, A. and Kennickell, Arthur B. "How Much (or Little) Life Cycle Is There in Micro Data? The Cases of the United States and Japan," in: Macroeconomics and Finance: Essays in Honer of Erance Modigliani. MIT Press, Cambridge MA, 1986.

Avery, Robert B. and Arthur B. Kennickell, "Savings and Wealth: Evidence from the 1986 survey of Consumer Finances," paper presented at the 50th Anniversary Conference on Research in Income and Wealth of the National Bureau of Economic Research. Forthcoming in a conference volume from the N.B.E.R.

Barro, Robert. "A Cross-Country Study of Growth, Saving, and Government," in this conference.

Becker, Gary, "A Theory of the Allocation of Time," Economic Journal, vol. 73, no. 5, pp. 493-517, September 1965.

Browning, Martin, Angus Deaton, and Margaret Irish. "A Profitable Approach to Labor Supply and Commodity Demands over the Life Cycle." Econometrica, Vol. 53, No. 3, May 1985.

Campbel1, John Y. \& Mankiw, N. G. (1989) "Consumption, Income, and Interest Rates: Reinterpreting the Time Series Evidence" N.B.E.R. Working Paper No. 2924, March 1989.

Deaton, Angus (1989). "Saving in Developing Countries: Theory and Review." Paper prepared for the First Annual World Bank Conference on Economic Growth.

Delong, J. Bradford and Lawrence H. Summers (1986), "Is Increased Price Flexibility Stabilizing?" in American Economic Review Vol. 76, No. 5. December 1986, pp. 1031-1044. 


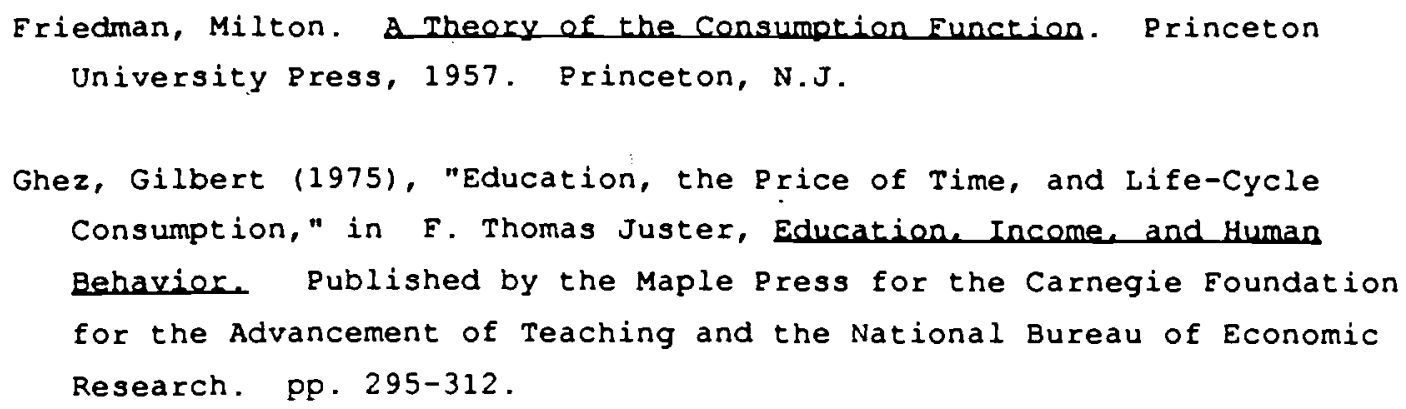


Nations," American Economic Review, Vol 76, No. 3 (June 1986), p. 297 .

Morgan Stanley, Capital International Perspective, various issues.

Romer, Paul. "Increasing Returns and Long-Run Growth," Journal of Political Economy, 94, October 1986, 1002-1037.

Statistics Canada, Eamily Expenditure in Canada. Statistics Canada catalog 62-555, 1989 .

United Nations, Department of International Economic and Social Affairs. Global Estimates and Projections of Population by Sex and Age. The 1984 Assessment, New York: 1987. 
</ref_section> 
Table 1

Regressions of Consumption Growth on Income Growth

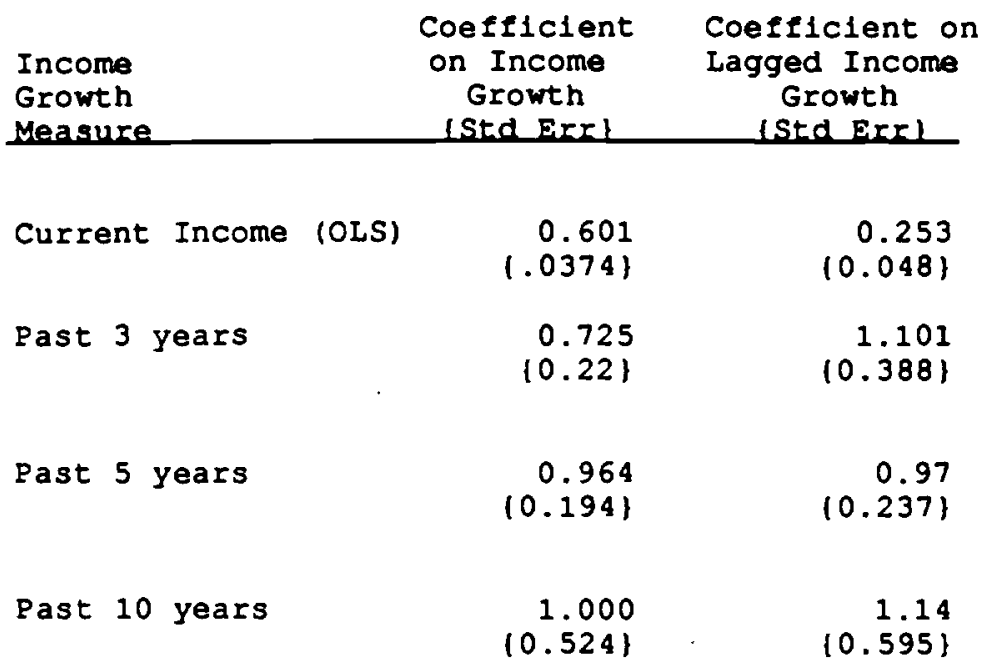

These equations were run over using the 15 countries described in the text.

Data for 1960-1985 were used, and dummies for each year (not reported) were included in all regressions.

Equation 1 runs current consumption growth on current income growth

Equation 2 forms an expectation of current income growth using the average income growth over the past three years

Equations 3 and 4 form expectations using previous five year and previous ten year growth rates

Column 1 gives the coefficient when the RHS variable is as fust described

column 2 gives the coefficlent using a one year lag of the varlable fust described 


\author{
Table 2: The Relationship Between Trade Balances and Growth Rates \\ Cross-Country \\ Correlation \\ between \\ Trade Balance \\ Samole Data \\ and Growth

$\begin{array}{llr}\text { 1961-1985 Averages of Growth and Balance } & 0.051 \\ \text { 1961-1973 Averages of Growth and Balance } & 0.213 \\ 1974-1985 \text { Averages of Growth and Balance } & 0.045 \\ & \\ 1961-1965 \text { Averages of Growth and Balance } & 0.113 \\ 1966-1970 \text { Averages of Growth and Balance } & 0.265 \\ 1971-1975 \text { Averages of Growth and Balance } & -0.116 \\ 1976-1980 \text { Averages of Growth and Balance } & -0.327 \\ 1981-1985 \text { Averages of Growth and Balance } & 0.222\end{array}$ \\ Source: DRI RIMF database for trade balance \\ DRI COECDNIA database for real GDP Growth
}




\section{Iotal Populatilen}

$\begin{array}{cl}\text { Number of } & \\ \text { Years with } & \text { Fraction of the } \\ <\$ 100 \text { in } & \text { Population } \\ \text { Interest and } & \text { falling in } \\ \text { Dividend Income } & \text { this category }\end{array}$

Fraction of
total labor
income that
goes to people
in this catogory

37.3

6.5

5.5

5.9

6.9

8.8

38.7

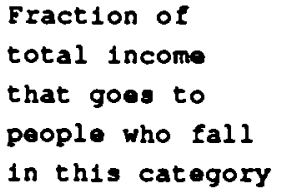

in this category

Fraction of total capital income that goes to people in this category

Under Age 65 pepulation

$\begin{array}{cl}\begin{array}{c}\text { Number of } \\ \text { Yeara with }\end{array} & \text { Fraction of the } \\ <\$ 100 \text { in } & \text { Population } \\ \text { Interest and } & \text { falling in } \\ \text { Dividend Income } & \text { this category }\end{array}$

Number of Yeara with $<\$ 100$ in Dividend Income

Fraction of
total labor
income that
goes to people
in this category

Fraction of total income

Fraction of total capital that goes to income that people who fall goes to people in this category in this category

$\begin{array}{llccc}0 & 35.2 & 39.7 & 47.4 & 92.8 \\ 1 & 6.2 & 7.8 & 7.1 & 2.8 \\ 2 & 5.2 & 6.0 & 5.3 & 1.7 \\ 3 & 5.3 & 6.3 & 5.8 & 1.0 \\ 4 & 6.1 & 6.7 & 5.9 & 0.7 \\ 5 & 7.8 & 7.9 & 6.7 & 0.4 \\ 6 & 34.2 & 25.6 & 21.8 & 0.3\end{array}$

Source: Calculations by Daniel Feenberg of the National Bureau of Economic Research See Appendix for more detalled discussion of calculations 
Table 4: Sources of Dividend and Interest Income

Whole Populatior

Interest and Dividend Income

$\begin{array}{lrr}\text { Netabted by } & \text { Mean } & \text { Median } \\ & & \\ \text { AGI } & 9344 & 544 \\ \text { Taxpayers } & 2755 & 185 \\ \text { Int Div Income } & 46533 & 16100 \\ \text { Estimated Assets } & 43840 & 14930\end{array}$

Adjusted Gross Income

\begin{tabular}{lrr} 
Wetchted by & Mean & Median \\
\hline & & \\
AGI & 62910 & 38537 \\
Taxpayers & 30069 & 24693 \\
Int Div Income & 101983 & 45728 \\
Estimated Assets & 99797 & 43883
\end{tabular}

Wage Income

Weiohted by Mean Median

AGI $\quad 42940 \quad 32923$

Taxpayers $25212 \quad 20995$

Int \& D IV Income $28198 \quad 6051$

Estimated Assets $27701 \quad 6361$

Estimated Assets

\begin{tabular}{lrr} 
Neianted by & Mean & Median \\
\hline & & \\
AGI & 162342 & 9966 \\
Taxpayers & 48914 & 3588 \\
Int \& Div Income & 778317 & 287375 \\
Estimated Assets & 753831 & 274893
\end{tabular}

Population Excluding Elderly

Interest and Dividend Income

Welahted by

Mean

Medtan

$\begin{array}{lll}\text { AGI } & 7878 & 364\end{array}$

Taxpayers $1600 \quad 113$

Int Div Income $62515 \quad 12657$

Estimated Assets $\quad 58401 \quad 11457$

Adjusted Gross Income

$\begin{array}{lrr}\text { Weiabted Dy } & \text { Mean } & \text { Median } \\ \text { AGI } & 63279 & 38773 \\ \text { Taxpayers } & 30481 & 25468 \\ \text { Int D Div Income } & 150050 & 56695 \\ \text { Estimated Assets } & 148073 & 53676\end{array}$

Wage Income

heighted by

Mean Median

AGI $\quad 45327 \quad 35248$

Taxpayers $\quad 27616 \quad 23439$

Int Div Income $45110 \quad 25960$

Estimated Assets $\quad 44750 \quad 26920$

Est imated Assets

$\begin{array}{lrr}\text { Neiahted Dy } & \text { Mean } & \text { Median } \\ & & \\ \text { AGI } & 137393 & 6735 \\ \text { Taxpayers } & 28282 & 2183 \\ \text { Int \& Div Income } & 1032177 & 224299 \\ \text { Estimated Assets } & 995144 & 212415\end{array}$

Source: Calculations by Daniel Feenberg of the N.B.E.R.

See Appendix for more detailed description

All figures in 1988 dollars 
Flgure 1 a

GNP Growth Rates

vs. Consumption Growth Rates,

Per Caplta, 2960-1985

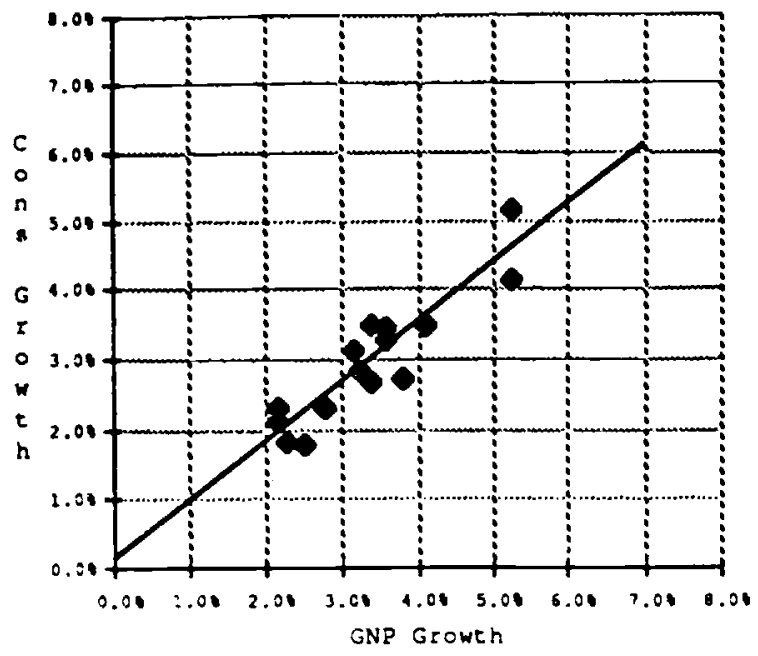

Figure lc

GNP Growth Rates vs.

Consumption Growth Rates

Per Caplta, 1980-1985

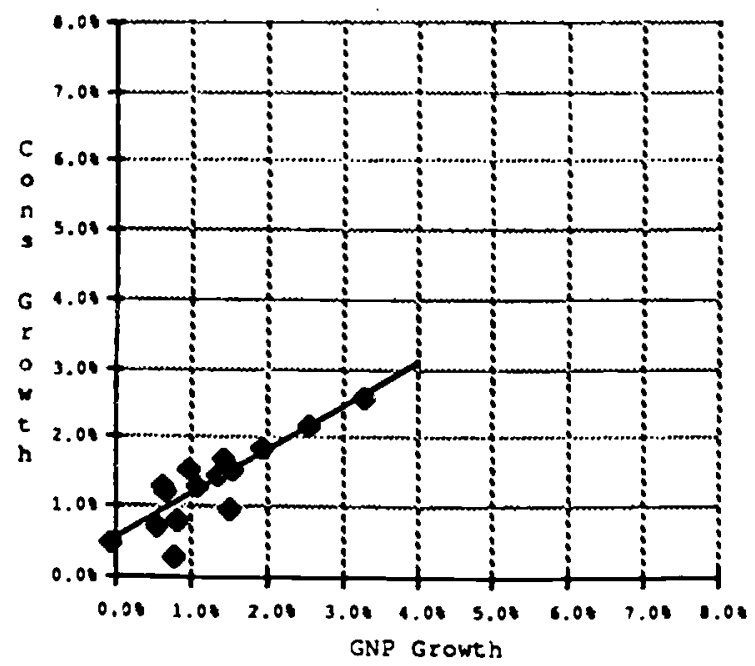

Figure ib

GNP Growth Rates vs.

Consumpt ion Growth Rates.

Per Caplta, 1960-1973

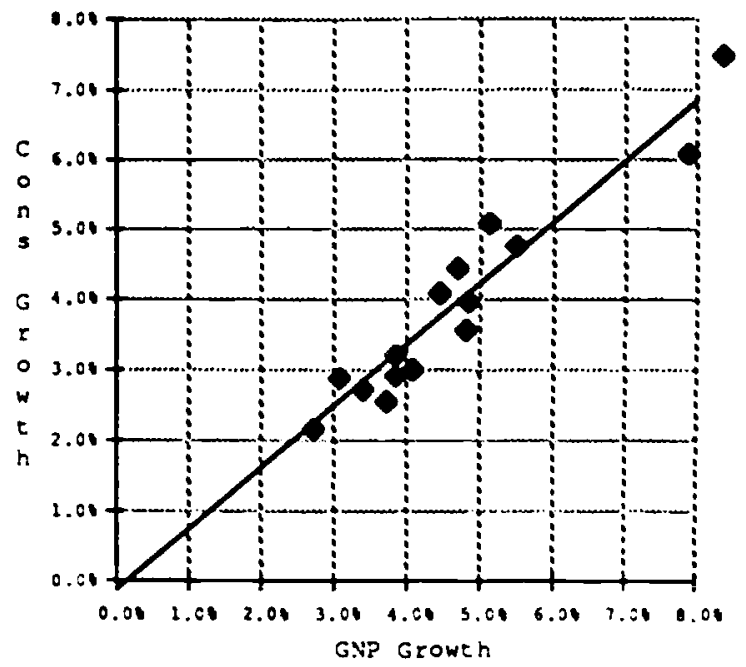

Flgure la

Change in Per Caplta GNP Growth Rates

vs. Change in Consumption Growt h

comparing period 60-73 to 82-85

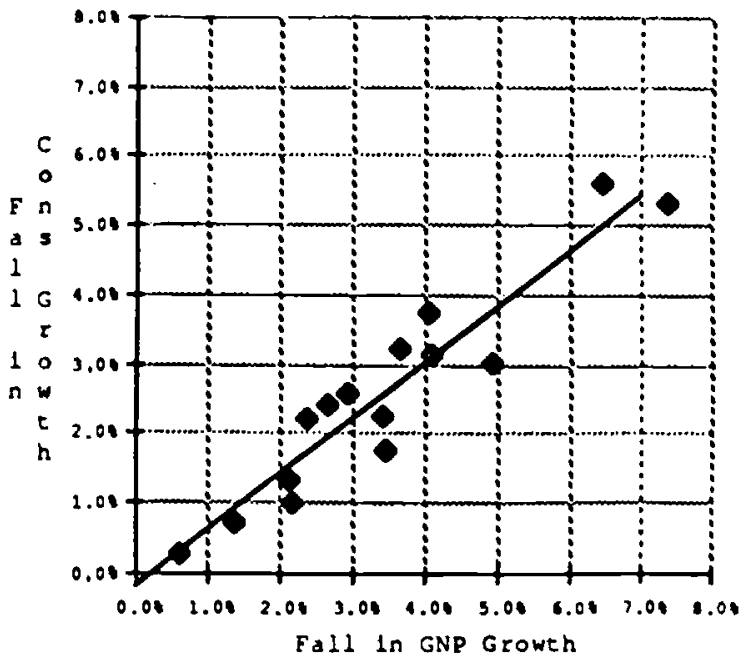


Figure 2

Per Caplea Income Growth

Projected 1988-2000 vs.

Actual 1976-1988

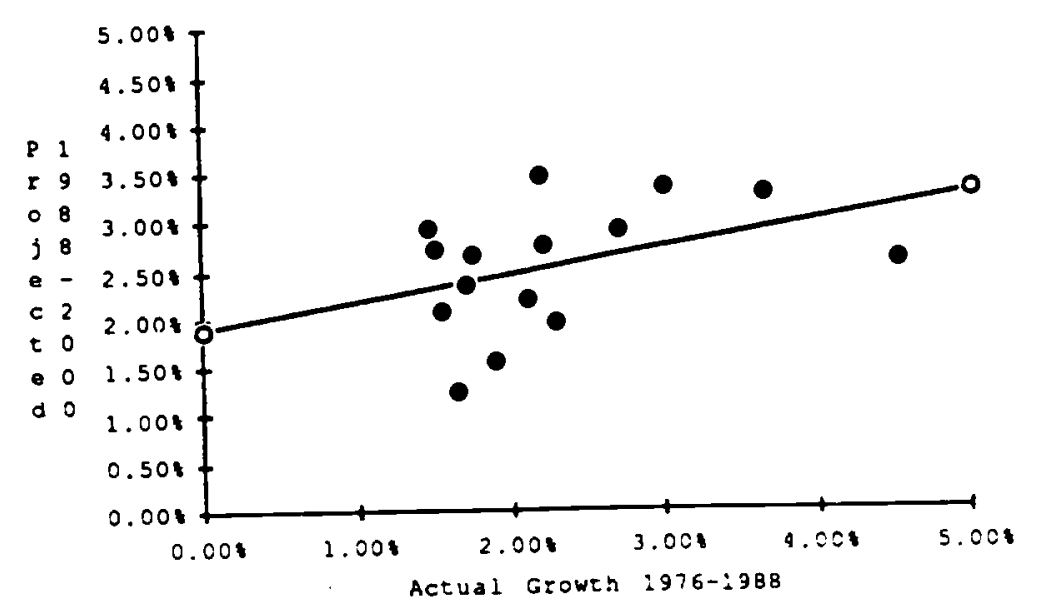


Flgure $3 a$

Consumpt Ion Growth Rates

Per Captta vs, Short Run

Real Interest Rates, 1960-85

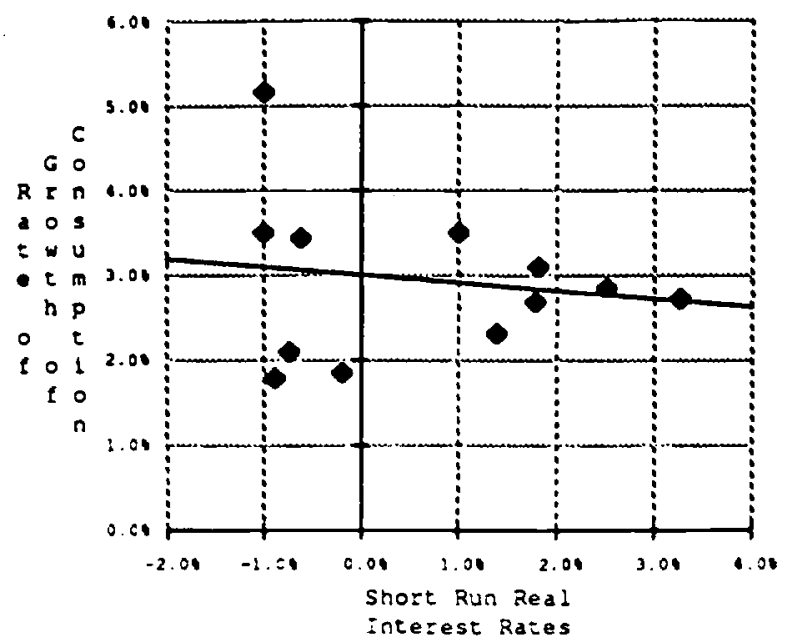

Eigure 3c

Consumption Per Captta

Growt Rates vs.

Average Dlvidend Y1eld, 1960-85

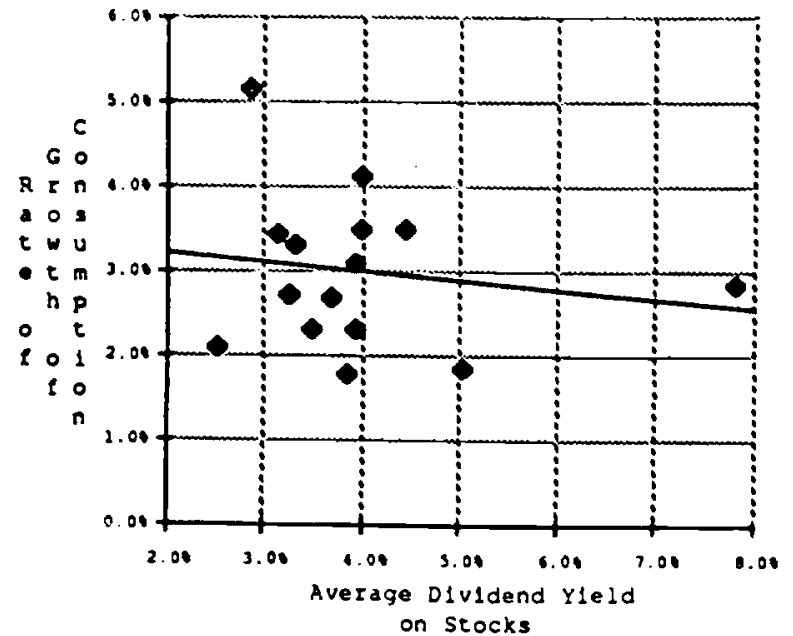

Flgure 3b

Consumption Growth

vs. Stock Market

Earnings Price Rat10

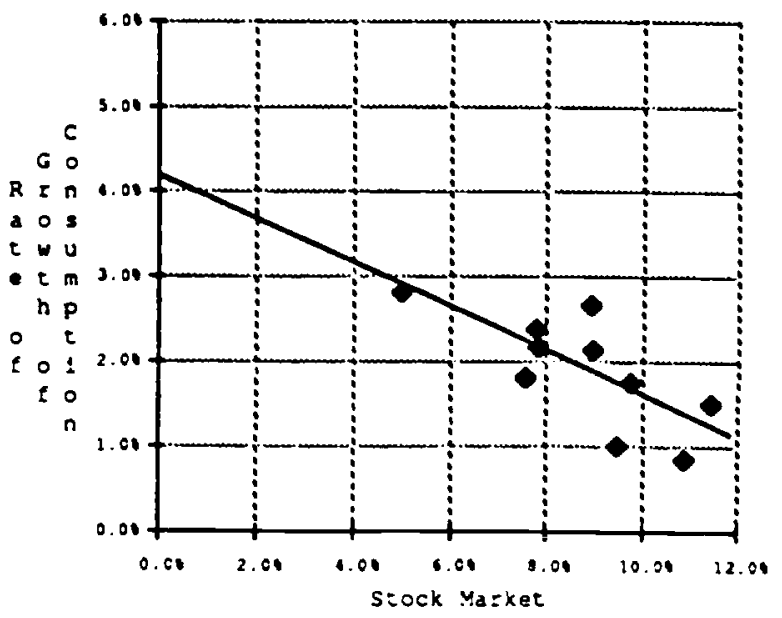

Earnings Price Ratio

Elguze $3 d$

Consumption Per Captea

Growth Races vs.

Average Reai Returns, 196:-85

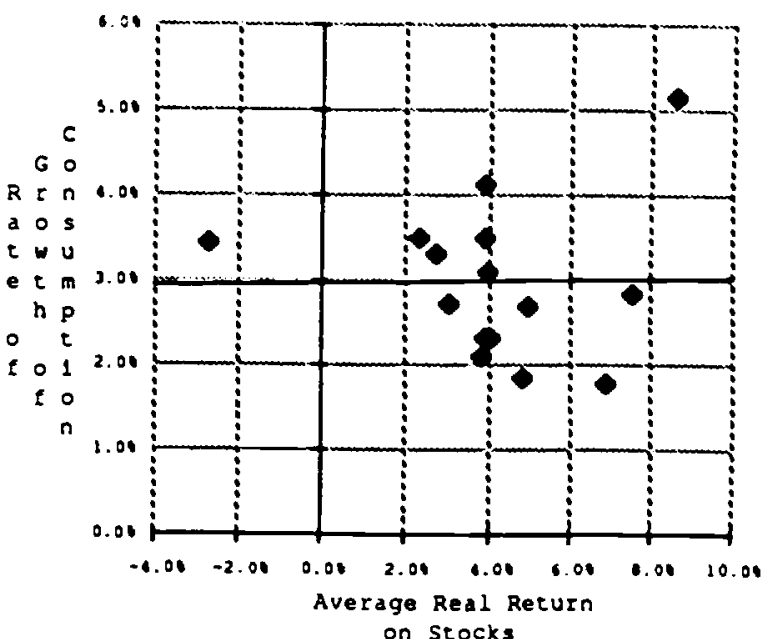


Figure 30

Change In Per Capita Consumption Growt

$v s$. Change in Real Interest Rates

Comparing Period 60-73 to 80-85

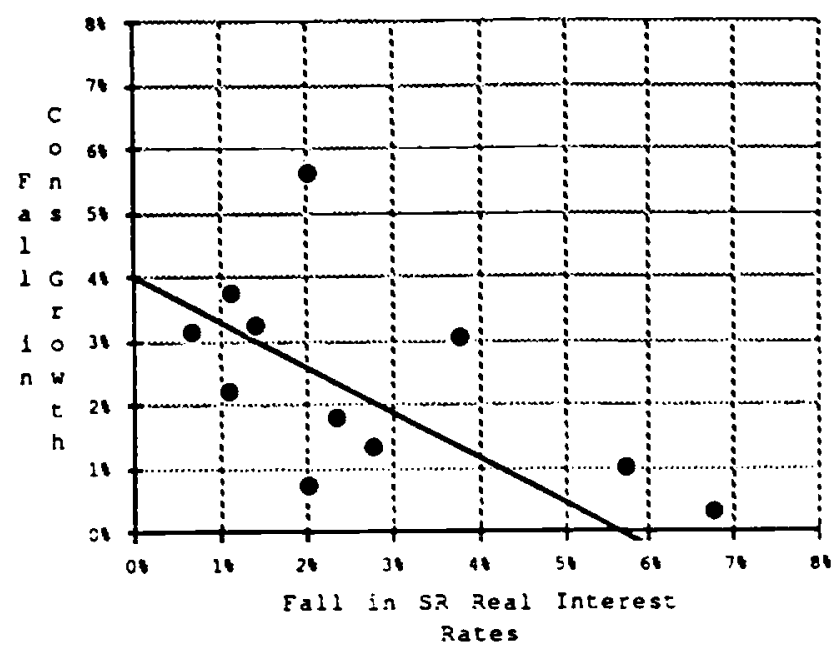




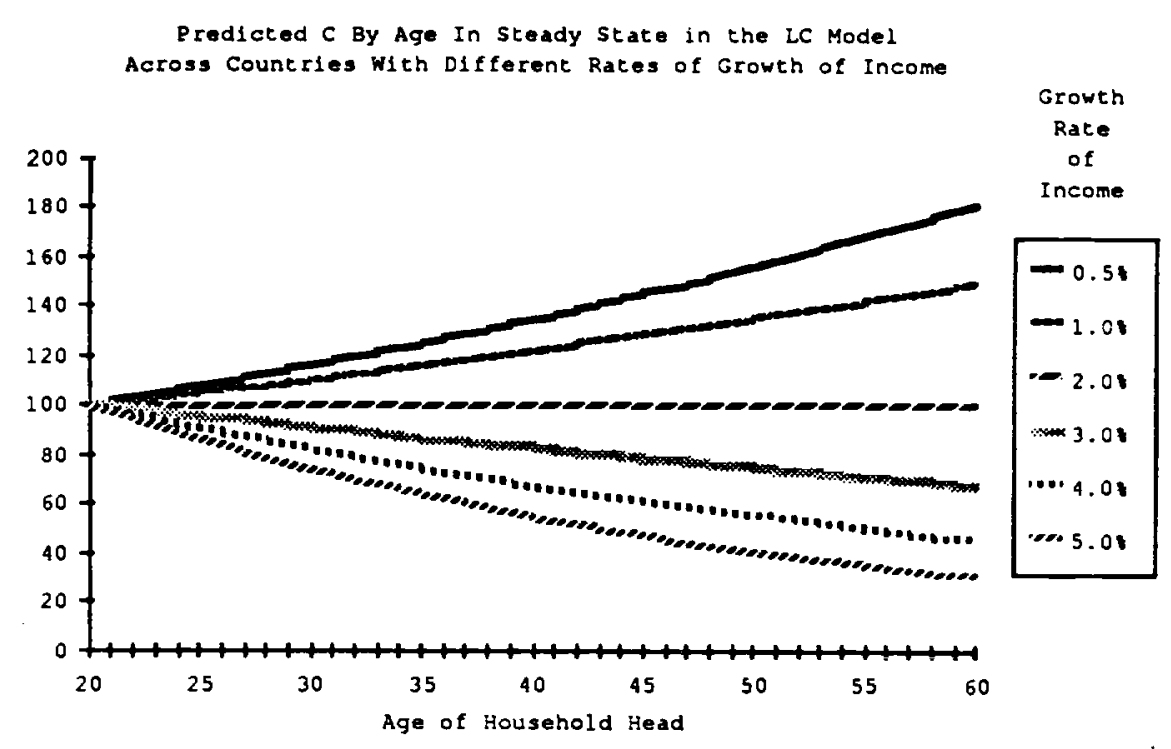

Flquie $4 b$

Age/Consumption Cross-Section Data

for the US, Canada, Japan, Britain, Denmark, and Norway

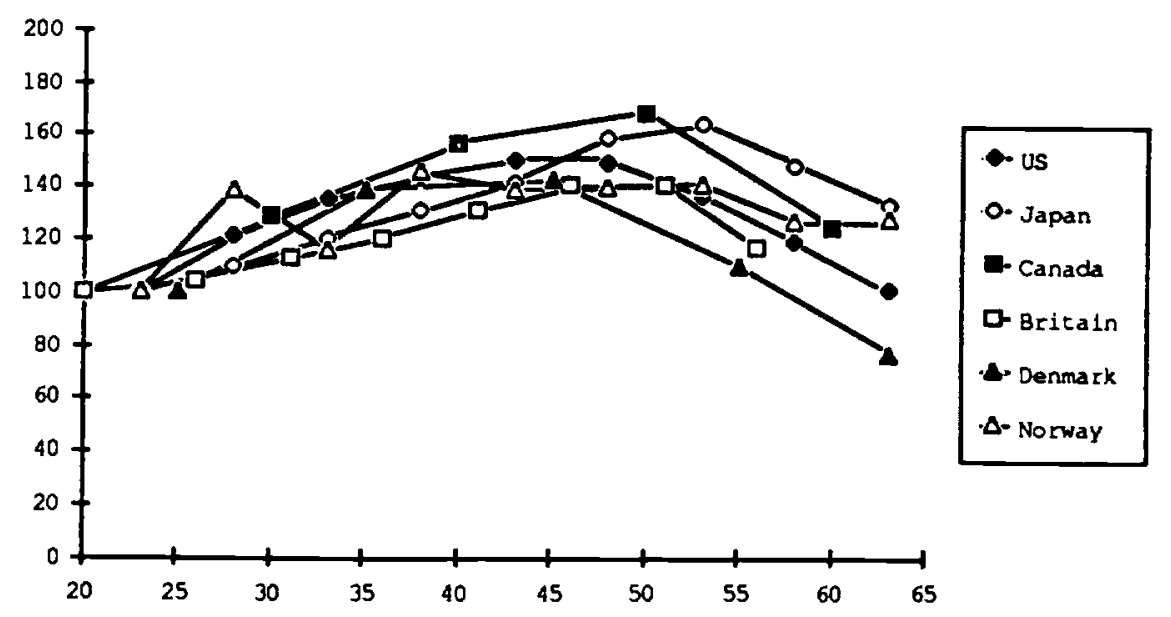


Flgure 5 a

Age Consumption Profiles for the U.S.

1960,1973 , and 1985

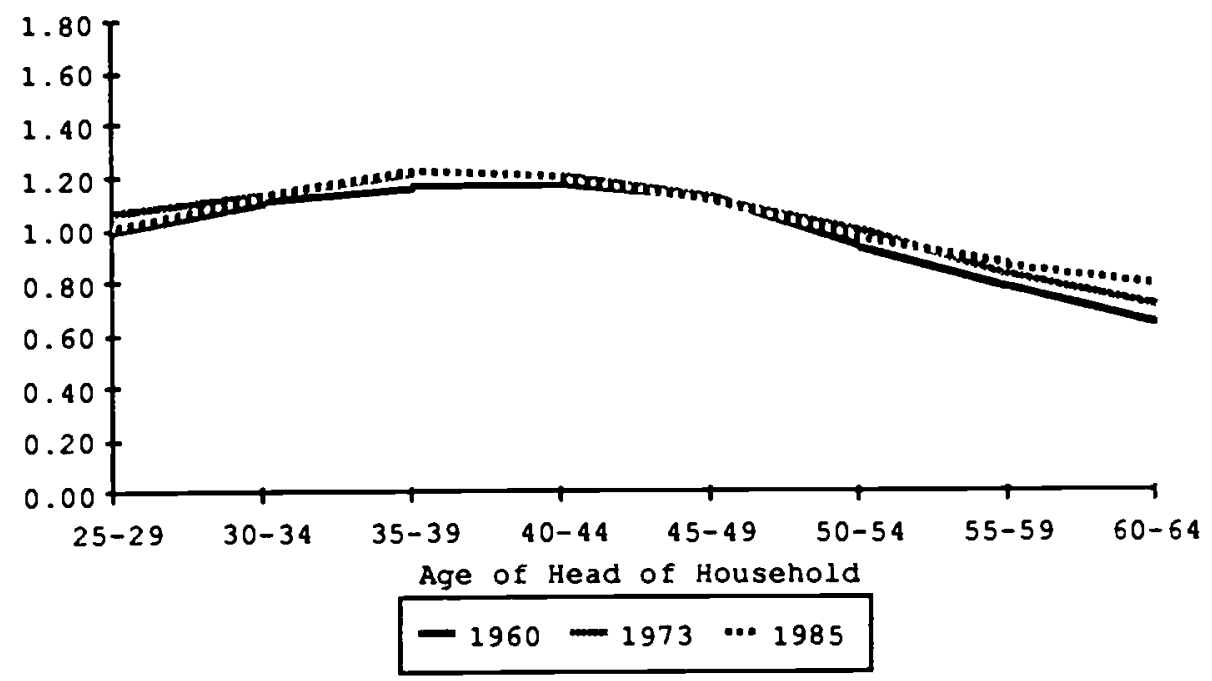

Figure 5b

Age Consumption Profiles for Japan

in 1974 and 1979

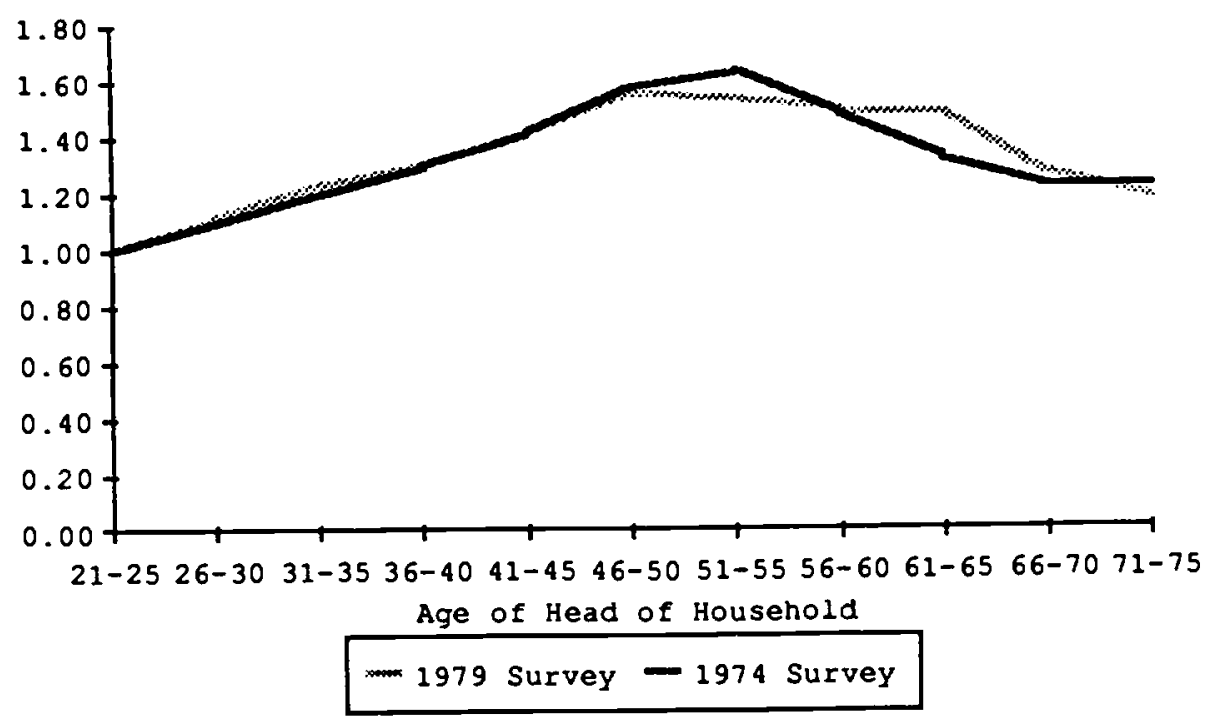


Consumption at Each Age for a Eamily Whose Head was Age 55 in 1985

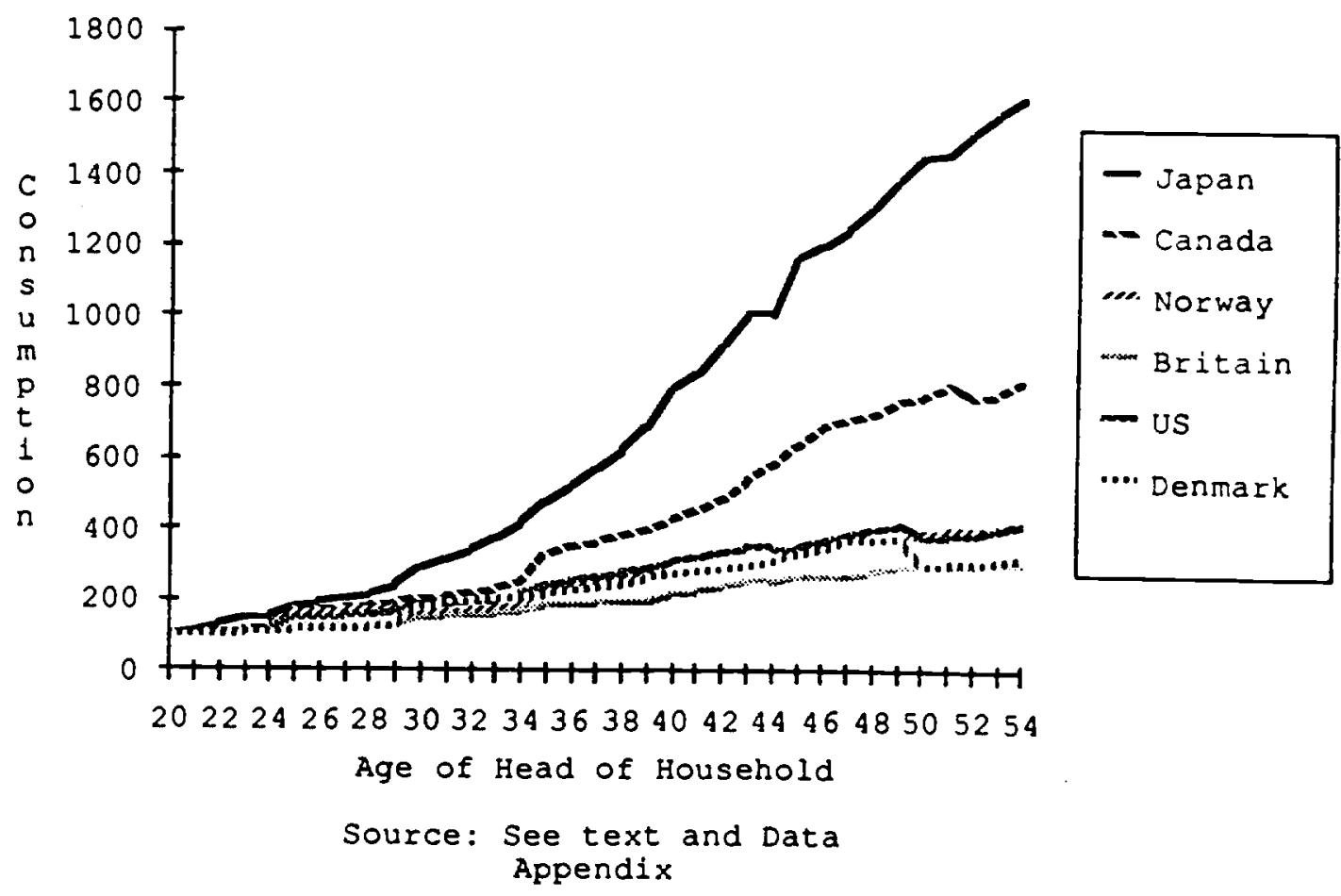


Figure Ta:

1960 CES Income/Consumption Prolines by Education

tom Grate shool

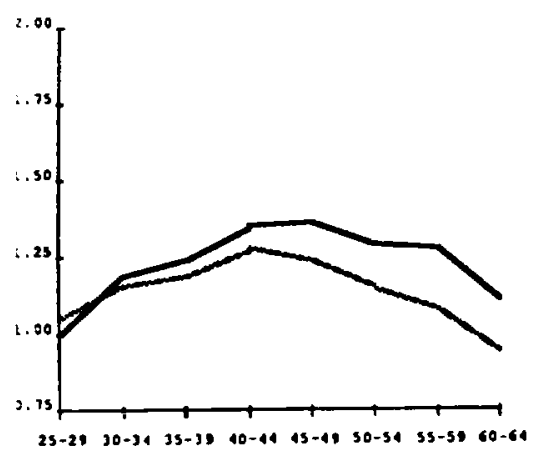

sow nigh school

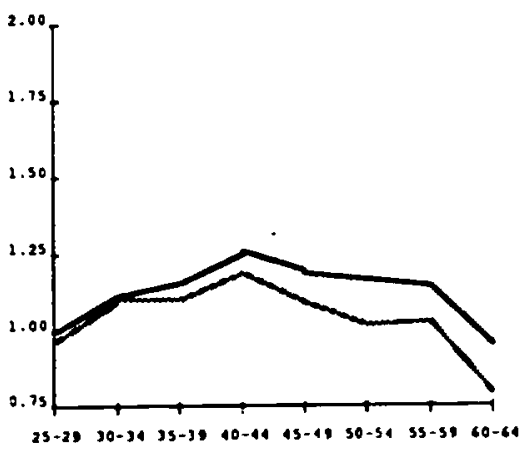

Finished Klan school

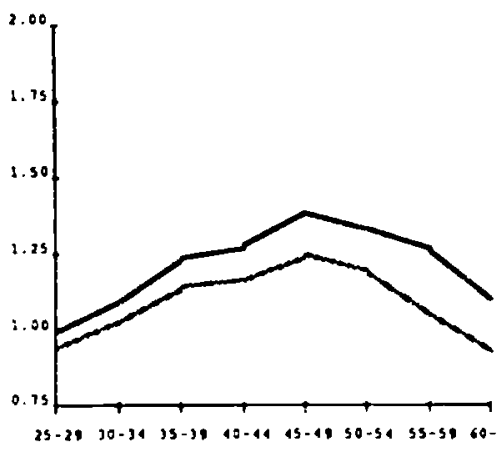

som college

Finished college
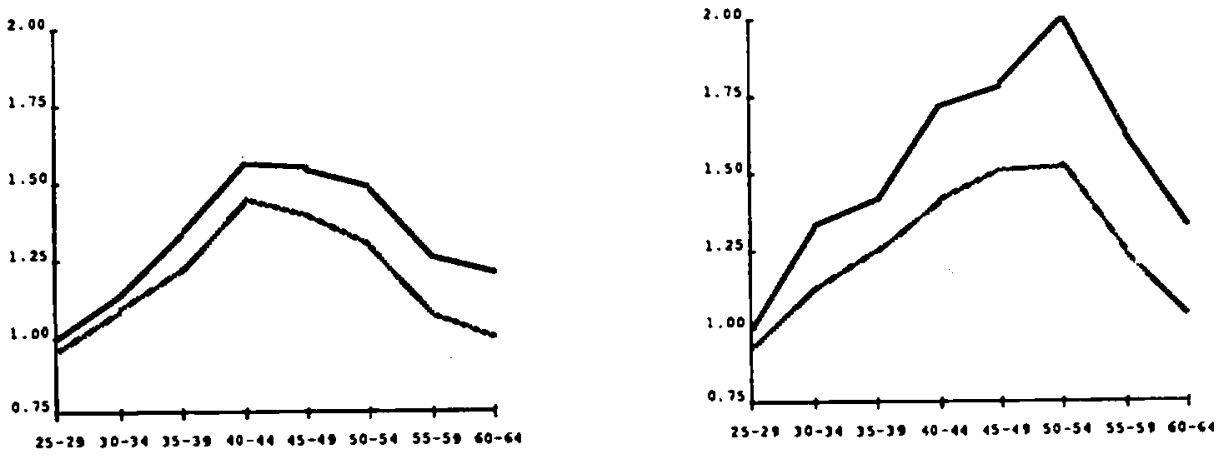

See the Data Appendix for details on the construction of Figures 7 and 8 . The darker line is disposable income and the lighter fine b consumption. 


$$
\begin{aligned}
& \text { E⿸릇 } \\
& \text { Leth } \\
& \text { Ertis }
\end{aligned}
$$


$\vec{E}$

E 
$\underline{E} \bar{E}$ ake $h \mathrm{hl}$ 

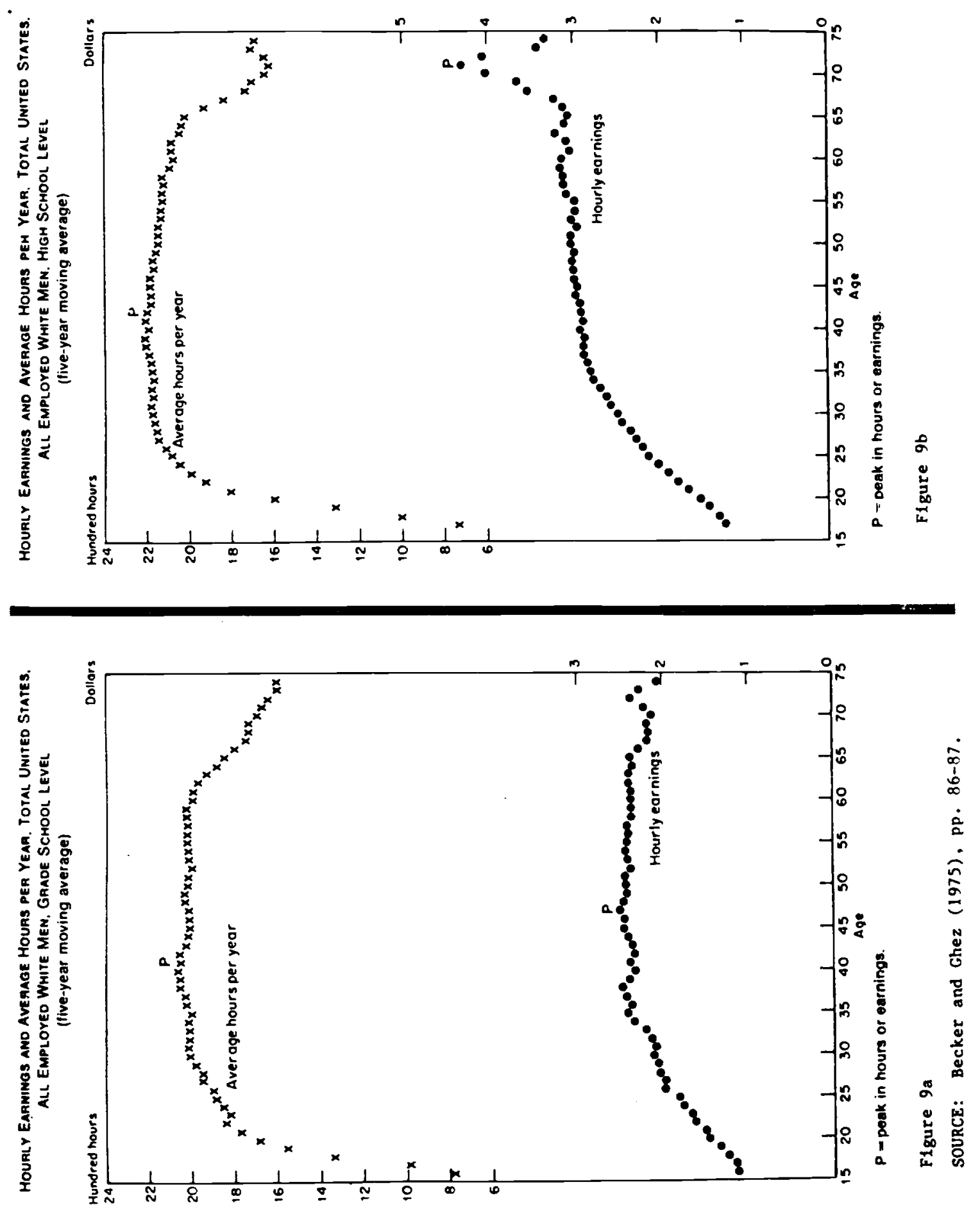


\begin{abstract}
Change in saving as a Fraction of Income If the Expected Growth Rate of Income Changes From 3 to 18 Per Capita Per Year, Calculated for Lifetime Consumption Growth Rates Ranging from -1 to 31
\end{abstract}

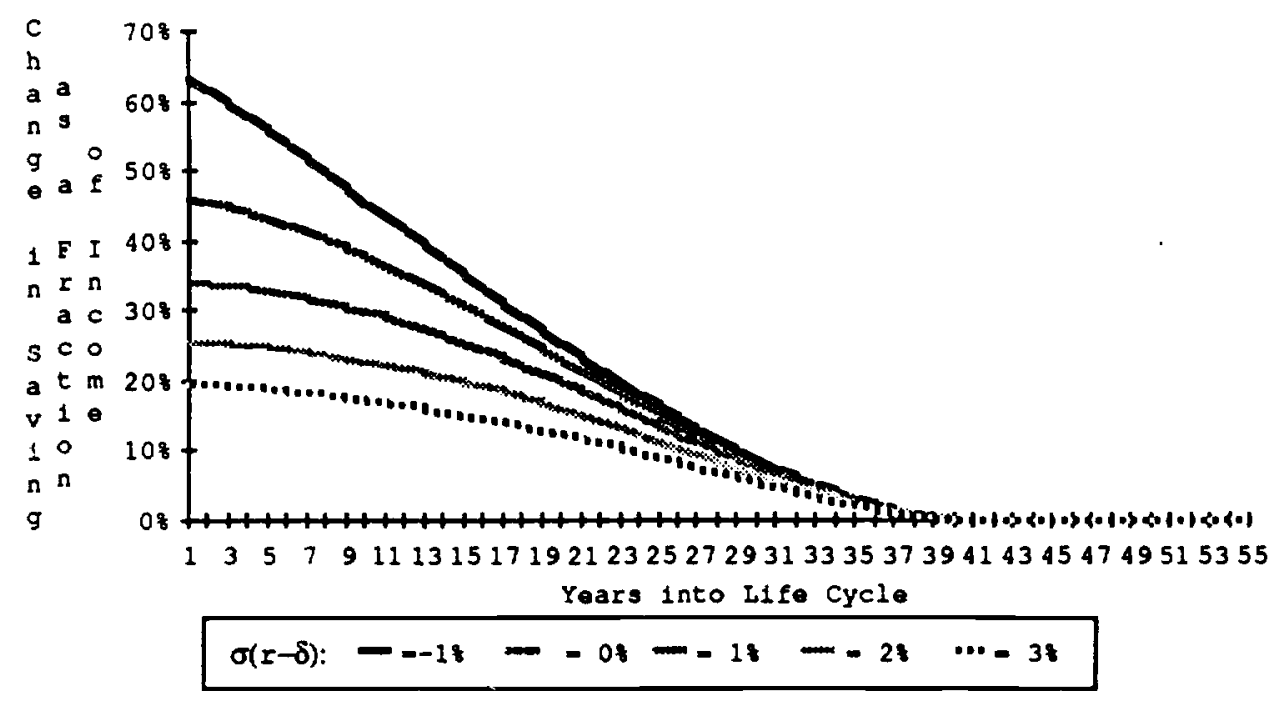


Figure 1la

Private Saving Rates Before 1973 vo. Private Saving Rates After 1973

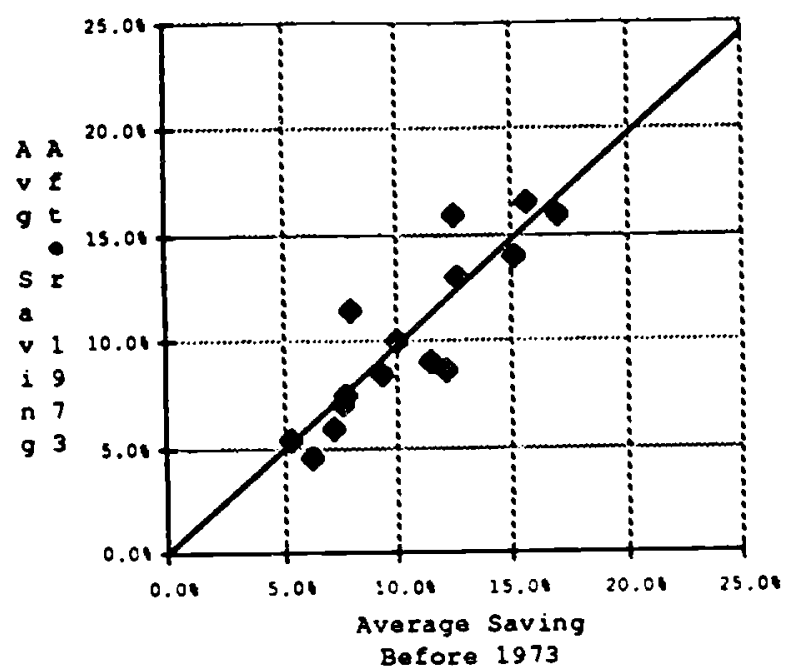

Eigure 11c

Fall In Private Saving Rates

vs. Fall In Growth Rates

(Average 1980-85 minus Average 1960-73)

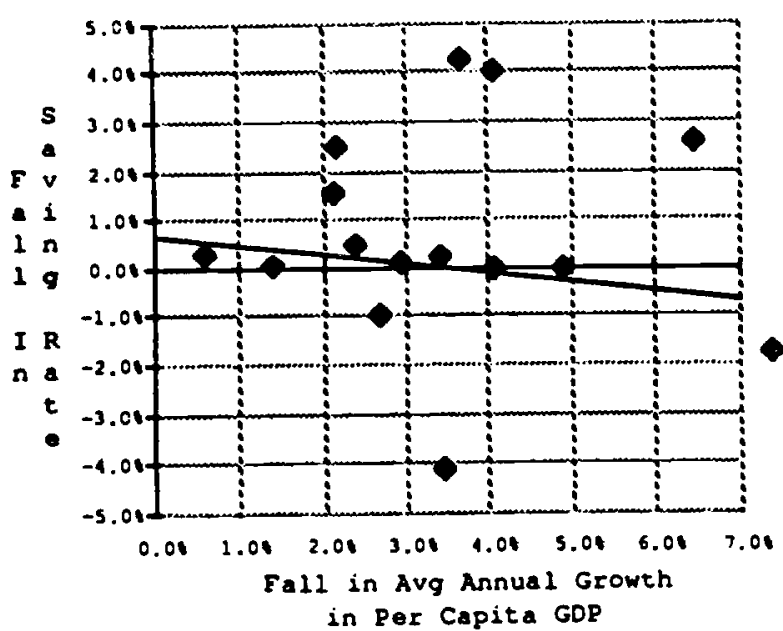

Figure $11 b$

National Saving Rates Before 1973

ve. National Saving Rates hLtez:373

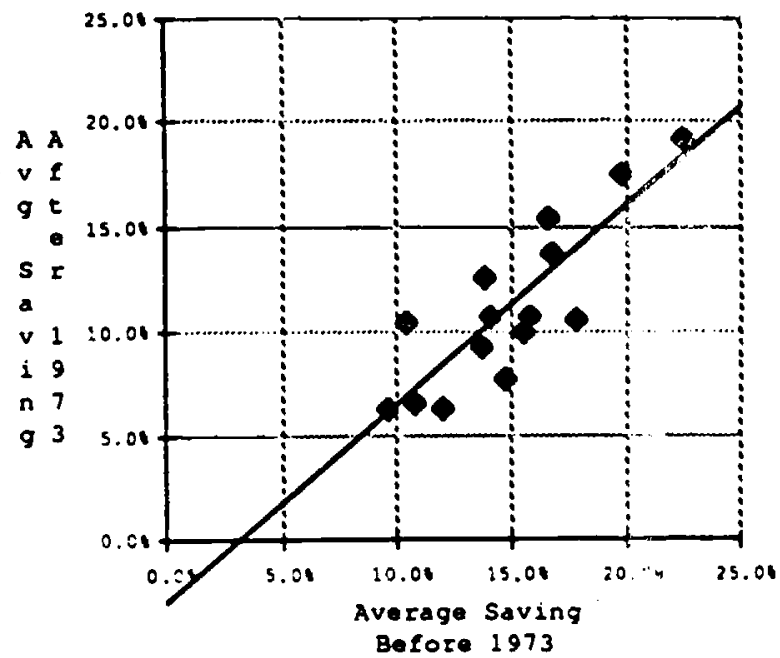

Figure $11 d$

Fall In National Saving Rates

vs. Fall In Growth Rat

(Average $1980-85$ minus Averags $1960-7$;

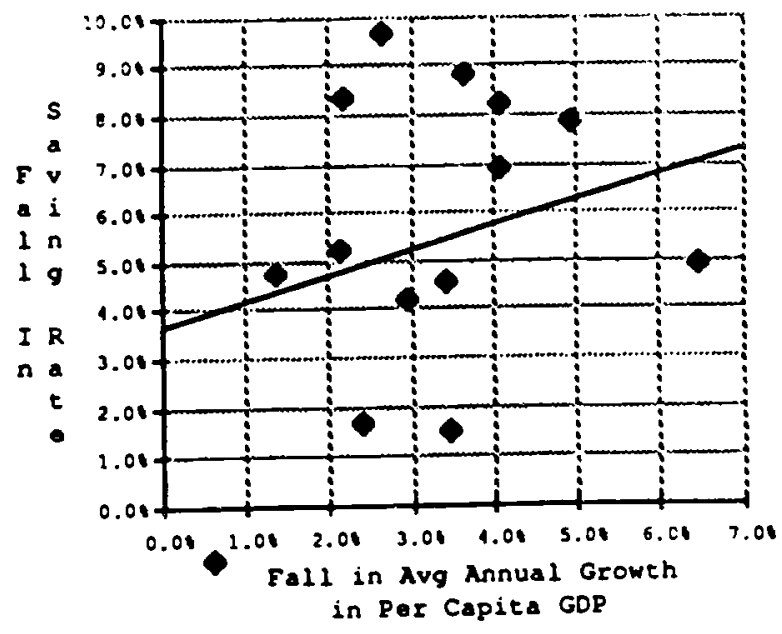


Figure 12

Saving Rates By Age in

1960, 1972, and 1985
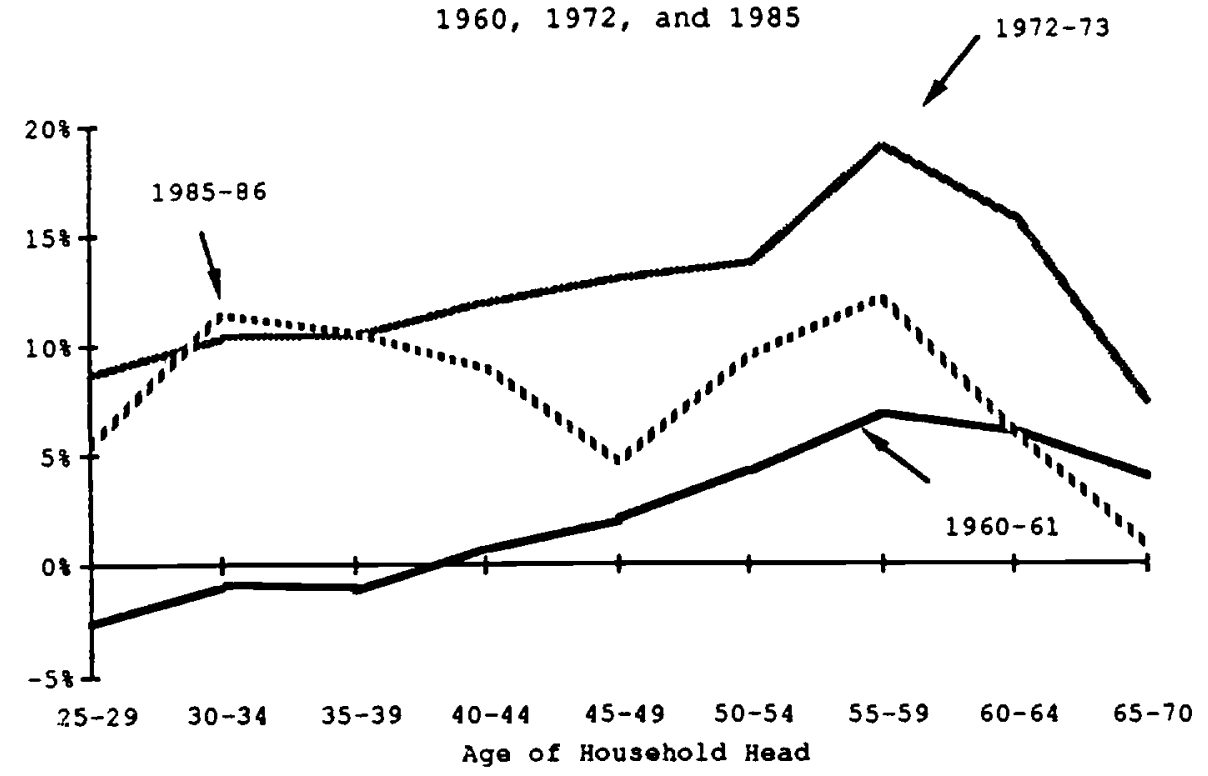
Figure $13 a$

Young Families' Saving as a Fraction of Incomo

Versus Future Income streams in Their Occupation

1960 CES

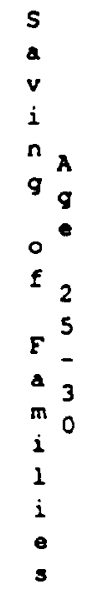

$\begin{array}{cc}15 t \\ 13 t \\ 91 \\ 9 & 91 \\ 2 & 7 t \\ 2 & 5 t \\ 5 & 3 t \\ 3 & 1 \\ 0 & -18 \\ -38 \\ -5\end{array}$

tit

Managers

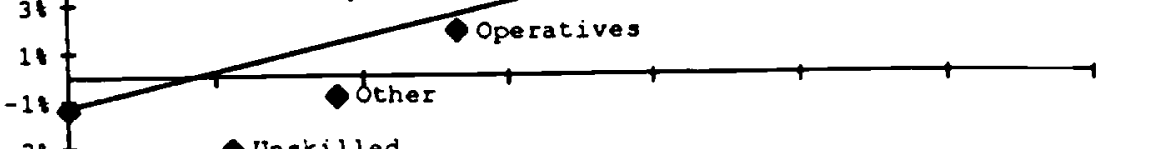

$-51$

7

7.5

8.5

Craftsmen

Unskilled

9

Incomes of Families Age 30-65

Divided By Current Income of Families

Age 25-30

Figura $13 b$

Young Families' Saving as a Fraction of Income

Versus Future Income Streams in Their Occupation

$1972-73$ CES

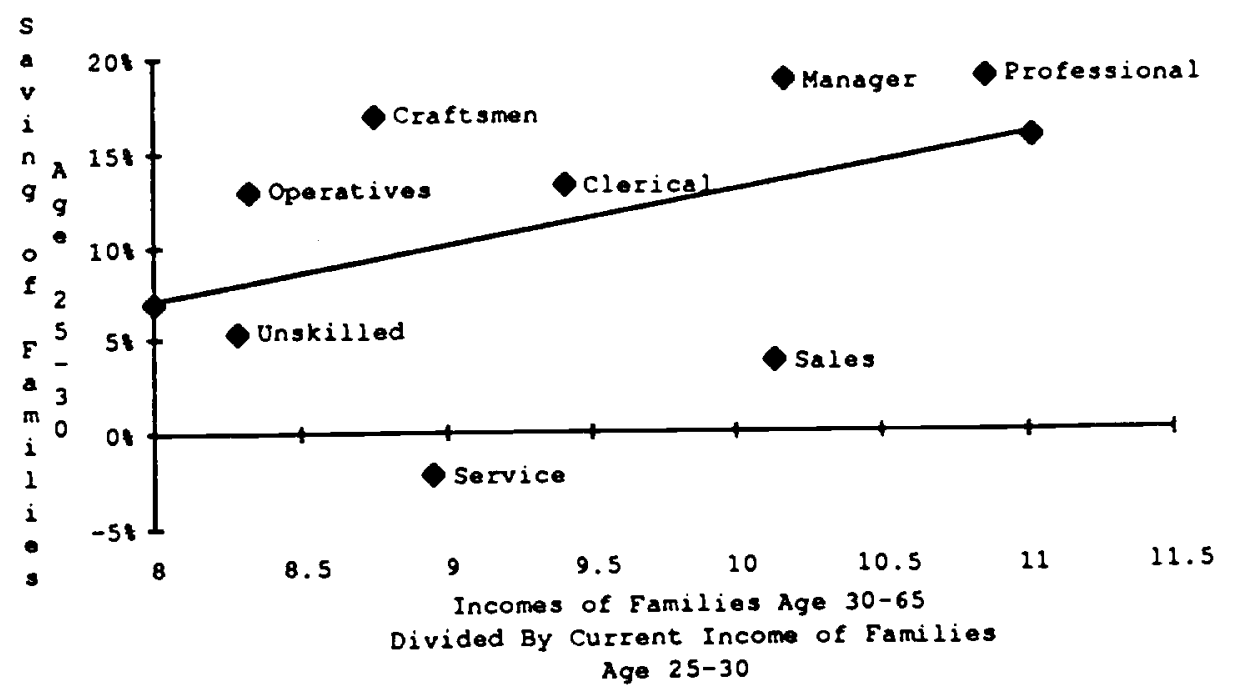

